\begin{tabular}{l|lr}
$\begin{array}{l}\text { Università } \\
\text { della } \\
\text { Svizzera } \\
\text { italiana }\end{array}$ & $\begin{array}{l}\text { Faculty } \\
\text { of Economics }\end{array}$ & IdEP Economic Papers \\
& & \\
\hline & & $2020 / 02$
\end{tabular}

P. Bello

Gender-based price discrimination in the annuity market: evidence from Chile 


\title{
Gender-based price discrimination in the annuity market: Evidence from Chile *
}

\author{
Piera Bello
}

July 9,2020

\begin{abstract}
This paper studies gender-based price discrimination in the annuity market. The dataset consists of transaction-level data on the universe of individuals accessing the Chilean annuity market in the 2004-2017 period. It exploits the fact that, in Chile, individuals can access the annuity market through three different channels: an independent financial advisor, a sales agent at a company, or directly at a PFA (Pension Fund Administrator). The analysis shows that sales agents severely distort prices to the detriment of women customers. Women who consult sales agents pay higher transaction prices compared to the other two groups of women, while there is no variation in men's prices across the three channels for market access. Additional evidence shows that this is not driven by differences in negotiation skills or type of annuity product purchased but rather by differences in initial prices. Firms charge higher initial prices to women who access the market through one of their sales agents. These results are consistent with an explanation that links the lack of competition between firms to discriminatory behaviour against female customers. Gender differences in financial literacy might explain why firms find it profitable to offer higher prices to women.
\end{abstract}

Keywords: annuity market, insurers, gender, bargaining, statistical inference. JEL classification codes: J16, C78, G22, G5, D81

*Institute of Economics, Università della Svizzera italiana. Present Address: 30 Gordon Street, Department of Economics, University College London. I am very grateful to Orazio Attanasio for his guidance and support. I would also like to thank James Bank, Vincenzo Galasso, Mario Padula, Ximena Quintanilla, Johanna Rickne and seminar participants at Università della Svizzera italiana, at University College London (CREAM Brown Bag seminar) and at University of Padua for insightful comments and discussions. Financial support from the Swiss National Science Foundation (grant Advanced Postdoc.Mobility -183874) is gratefully acknowledged. Usual disclaimers apply. 


\section{Introduction}

This paper studies gender-based price discrimination in the annuity market. In the last three decades, there has been a growing interest in the annuity market and in the role of pension funds in individual retirement life, as many countries have reformed their pension systems, switching from pay-as-you-go systems towards individual savings schemes. In countries with funded defined-contribution pension schemes, upon retirement, individuals face the decision of whether to convert their fund into a retirement income via the purchase of an annuity or to withdraw their pension savings as a lump-sum. This decision represents one of the biggest decisions of a person's lifetime as once purchased an annuity cannot be refunded and keeps paying the negotiated income for the rest of the individual's life.

The Chilean reform in 1980, which replaced the pay-as-you-go regime with a fully-funded pension system based on individual accounts run by private pension funds, is considered one of the most successful reforms and an example for many other countries. Yet, the adequacy of the system is now being questioned, as it delivers poor pension outcomes. Most individuals seem to not have saved enough, and women are especially hard-hit. The system uses sex-specific mortality tables to price retirement benefits, and women are allowed to retire much earlier than men. These facts, combined with women's generally lower earnings levels, mean that women's benefits are relatively low compared to men's. Moreover, buying an annuity is not a simple task, and since women have lower financial skills they face additional challenges in achieving an adequate retirement income. Finally, a lack of competition has allowed the private companies, known as PFAs (Pension Fund Administrators), which manage the pension funds, to earn disproportionately high fees. For all these reasons, investigating whether there is gender price discrimination in such a market, and eventually the source of these price differentials appears extremely important.

Previous literature has documented the presence of gender-based price discrimination in other markets, such as the automobile market (Ayres and Siegelman, 1995; Goldberg, 1996), the sports card market (List, 2004), the drug market (Fitzpatrick, 2017) and the credit market (Alesina et al., 2013). These studies document a strong tendency for women to receive prices that are higher than those received by men. Interestingly, larger differences are found in initial prices, while final prices are often equivalent across gender. For instance, Goldberg (1996), using survey data on dealer discounts for the US car market, found that even though transaction prices do not differ by gender, women obtain, on average, larger discounts, and their purchases are characterized by higher variance. This evidence is consistent with women receiving, initially, higher prices than men do. Similar evidence exists for the Ugandan malaria drug market. Fitzpatrick (2017) shows that initial prices are higher for women than men; however, women negotiate, on average, larger discounts such that final prices do not differ by gender. However, for the sports card market, List (2004) shows that only experienced minorities are able to obtain final offers that are statistically equivalent to the final offers received by 
their majority counterparts, while non-experienced minorities pay higher transaction prices. Finally, for the financial markets, the only existing contribution focuses on credit markets (Alesina et al., 2013) and shows that, in Italy, female business owners pay higher interest rates than their male counterparts conditional to the same risk characteristics.

In this paper, I provide evidence of a similar discriminatory behaviour against women in the annuity market. Moreover, this paper contributes to the existing literature by linking this behaviour to a lack of competition in the market across annuity providers. I exploit the fact that, in Chile, individuals can access the centralised and electronic market for annuities (known as SCOMP) through a sales agent, an independent financial advisor, or directly. By using transaction-level data on the universe of retirees in the 2004-2017 period, I show that women accessing the market through a sales agent pay higher transaction prices compared to similar women accessing the market through an independent financial advisor or without any intermediary, while no differences across channels are found for men. Additional evidence shows that these three different channels are characterized by different levels of competition among annuity providers - the majority of people consulting a sales agent purchase the annuity from the sales agent's firm, regardless of its price. This is explained by the fact that sales agents receive a commission only if the individual purchases an annuity from their own company, so they have an incentive to capture customers once they have been contacted. In contrast, advisors get paid irrespective of which provider the individual purchases the retirement product from and seem to be helpful in assisting people's decision making. This evidence is in line with previous studies documenting that sales agents provide biased advice and tend to recommend products that provide high commissions to themselves (Anagol et al., 2017). However, unlike the existing literature, I also assess the joint role played by the sales agents' firm in shaping transaction prices. I show that the observed differences in final prices are neither the result of the negotiation process nor are driven by differences in the type of annuity product purchased or the selected firm - choices that are likely to be influenced by both the intermediary's behaviour and individual preferences- but rather they reflect differences in initial prices. I document that the initial prices firms charge women accessing the market through one of their sales agents are higher than those that the same firms offer to similar women accessing the market through a different channel or a different intermediary. No evidence for this behaviour is found for men.

Goldberg (1996) suggests that the tendency of offering prices that are higher for women than for men might be driven by statistical discrimination. She hypotheses that women might have more dispersed reservation values than men and that firms, by learning about these differences from previous transactions, offer prices that are higher for women than for men in order to extract a rent from high-reservation value individuals. ${ }^{1}$ For the annuity market, financial literacy represents an important factor influencing the reservation price. Women

\footnotetext{
${ }^{1}$ Evidence for this hypothesis has been provided by List (2004) by using data on the willingness to pay from bilateral negotiations in the sports card market.
} 
are found to have a lower level of financial skills than men even conditional to the same age, education level, and income. This seems to affect their financial decisions at retirement (Lusardi and Mitchell, 2008; Dwyer et al., 2002; Agnew et al., 2003). From this, it follows that women might vacillate more than men in their judgment about the fair price of an annuity and be more likely to purchase annuities that are unfairly priced. This gives an incentive to firms to charge higher initial prices to women than to men. Of course, such gender-base price discrimination is only possible when firms have market power.

A similar idea is present in recent papers analysing the role of financial advisors and documenting how the advice changes according to the type of clients, in particular, with respect to their levels of financial sophistication (Gabaix and Laibson, 2006; Inderst and Ottaviani, 2012; Georgarakos and Inderst, 2014; Bucher-Koenen et al., 2019). The hypothesis is that individuals with a higher level of financial literacy have a better understanding of financial matters and are more likely to recognise and, in turn, reject bad advice than are less informed clients. Advisors try to infer advisees' financial literacy from observable traits, like gender, and have an incentive to suggest worse options, which may be more lucrative to themselves, to individuals who seem to have low literacy. In the Chilean annuity market, financial advisors get paid in any event and do not have any incentive to recommend dominated products. On the contrary, sales agents have an incentive to suggest the annuity offered from their own firm but without differences across gender. However, if women have a worse understanding of the matter compared to men, the sales agent's firms have an incentive to exploit their market power and charge higher prices to women. Consistent with this hypothesis, I find that the increase in transaction prices observed in the case of a sales agent is lower among women coming from highly educated municipalities.

The paper is organized as follows. Section 2 presents an overview of the Chilean pension system. Section 3 describes the dataset and reports summary statistics of the sample. Section 4 presents the conceptual framework and empirical strategy. Section 5 contains the main analysis. Section 6 discusses the results. Finally, Section 7 concludes.

\section{The Chilean Pension System}

The Chilean pension system is based on two pillars. The first pillar consists of a noncontributory, publicly financed, means-tested PAYGO system, while the second one, the Pension Fund Manager program, is a national defined-contribution scheme. Individuals contribute $10 \%$ of their income and the normal retirement age is 65 for men and 60 for women. ${ }^{2}$ Early retirement is allowed at any age as long as individuals meet certain pension eligibility requirements. ${ }^{3}$ At retirement, they can decide to gradually withdraw their pension benefits or

\footnotetext{
${ }^{2}$ Individuals are not required to stop working to claim a pension benefit.

${ }^{3}$ The first requirement is that the benefit must be at least equal to $80 \%$ of the PMAS, the maximum welfare pension. The second requirement is that the pension must be at least equal to $70 \%$ of the average income in
} 
purchase a life annuity. If they choose the programmed withdrawal option, funds remain in the individual account and are paid by PFA through a decreasing pension until the funds are depleted. In the case of an annuity, the individual receives, from an insurance company, a real constant pension payment until death. Annuities may only be bought by individuals who can finance a pension higher than a certain threshold. Those who do not meet this requirement are entitled to a Basic Solidarity Pension.

Since 2004, workers must use an electronic quotation system, known as SCOMP, to access their accumulated pension savings. To enter the system, the potential retiree or beneficiary must request a "certificate of balance" from his/her PFA and then sign the "Request for offers" form. The electronic market can be accessed directly by the individual at a PFA or through an intermediary, such as a sales agent, who works for a specific firm, or an independent financial advisor. ${ }^{4}$ In the form, individuals indicate the retirement products they are available to purchase (immediate life annuity, temporary income with a deferred life annuity, an immediate life annuity combined with a programmed withdrawal, a programmed withdrawal), and the length of the guarantee period or deferral period if this applies. ${ }^{5}$ Annuity contracts for married individuals are regulated to be joint annuities. ${ }^{6}$ The form also provides the system with the following information of the individual: age, sex, municipality, marital status, presence of beneficiaries, pension account balance, and pension type. Upon receiving the information, insurance companies can decide whether or not to make an offer to a specific individual and then, eventually, provide a quotation for some or all of the annuity products an individual is available to purchase. ${ }^{7}$ The worker receives the offer through a "certificate of offers", which is valid for 15 days. The worker can then accept one of the alternatives, make a new query in the system, request an auction, request an external offer, or decline all offers and go back to the market at some point in the future. ${ }^{8}$ In the case of an external offer, the individual enters a bargaining stage. They can physically travel to one or more firms who had previously made an offer through SCOMP to try to negotiate a better price. Upon receiving the external offers, the individual can choose either to buy a product from the final choice set, which includes internal and external offers, or decide to delay retirement.

\footnotetext{
the ten years before claiming a pension.

${ }^{4}$ With the same certificate of balance, an individual can make up to three consultations in the system.

${ }^{5}$ Workers can take a partial lump-sum only if the remaining balance is sufficient to finance a pension equal to at least 70 percent of the average real wage of the worker in the 10 years preceding retirement and 150 percent of the MPG.

${ }^{6}$ This is only the case for married women after 2007. A joint annuity is an annuity that continues to make regular payments as long as one spouse lives. During the survivorship of annuitant, the annuity is paid at the full level. After the death of the annuitant, if the spouse is still surviving, he/she receives $60 \%$ of the previous level.

${ }^{7}$ There is no regulation impeding price discrimination based on any of the characteristics firms observe through SCOMP. Moreover, firms do not observe offers made by the other firms in the market. Firms make offers simultaneously.

${ }^{8}$ During the period of validity of the certificate of balance (35 days), they can make up to three consultations.
} 
Those individuals consulting an intermediary and requesting an external offer pay a commission. In the case of a sales agent, the individual pays a commission equal to up to $2 \%$ of their pension fund, but only if they end-up purchasing the annuity from the sales agent's firm. In the case of an independent financial advisor, the intermediary gets paid in any event instead. If the individual opts for the programmed withdrawal option, the advisor receives a commission equal to a maximum of $1.2 \%$ of the retiree's fund, while in the case of an annuity the commission is equal to up to $2 \%$ of the retiree's fund. ${ }^{9}$ Individuals who access the market directly do not pay any commission. External offers are net of this commission and cannot be lower than the respective initial offers.

In Figure A.1, I provide a diagram illustrating the functioning of the system.

\section{Data}

I use administrative individual-level data on all the requests, quotes, and annuity choices of the entire population of individuals entering SCOMP from 2004 to 2017. The dataset includes a firm identifier and information about bids as well as contract and firm characteristics. Moreover, for those individuals who decide to retire, I observe the date of birth, gender, municipality of residence, wealth, and beneficiaries. I restrict my analysis to annuity offers for an immediate life annuity, namely, an annuity without a deferral period and involving no withdrawal. ${ }^{10}$ Moreover, I exclude those individuals entitled to disability pensions and requests and offers made to beneficiaries from my sample. My final dataset consists of 334,000 potential retirees, and around 16 million annuity offers.

\subsection{Annuity Prices}

For each offer, I compute the corresponding price of the annuity. The conventional measure used by economists to determine the price of an annuity is the Money's Worth Ratio (MWR), which is the expected present discounted value of annuity payments divided by the initial premium. One minus the MWR represents the price of the annuity.

\footnotetext{
${ }^{9}$ The system was reformed in 2008. Before November 2008, the maximum commission for annuities was $2.5 \%$ for both types of intermediaries, and there was no commission in the case of a programmed withdrawals option.

${ }^{10}$ I decided to focus only on immediate life annuity offers because comparing the values of the offers across firms for deferral annuities would be less accurate as the offer may differ in two dimensions: the income received during the deferral period and the monetary value of the annuity received after that. Individuals who purchase an immediate life annuity represent half of those opting for an annuity. Specifically, on average, $33 \%$ of individuals of the initial sample purchase an immediate life annuity, $32 \%$ a deferred annuity, and less than $1 \%$ a combination of an annuity and a programmed withdrawal. The remaining share opts for the complete withdrawal option.
} 
The MWR for a single annuity is defined as follows:

$$
M W R_{i}=\frac{A_{i}}{P} \sum_{t=1}^{12(w-x)} \frac{{ }_{t} p_{x}}{\left(1+i_{t}\right)^{t}}
$$

here $\mathrm{A}$ is the monthly annuity payment, $\mathrm{w}$ is the ultimate age in the mortality table, ${ }_{t} p_{x}$ is the probability that a life aged $\mathrm{x}$ is still alive at time $\mathrm{t}$, it is the interest rate used for discounting future payments, $\mathrm{P}$ is the premium paid to the life insurance company. In the case of guarantee periods, ${ }_{t} p_{x}$ assumes value 1 for the period covered by the guarantee.

Similarly, for a joint annuity, the MWR is defined as:

$$
M W R_{i}=\frac{A_{i}}{P} \sum_{t=1}^{12(w-x)} \frac{{ }_{t} p_{x}+0.6_{t}\left(1-p_{x}\right)_{t} p_{y}}{\left(1+i_{t}\right)^{t}}
$$

where ${ }_{t} p_{x}$ indicates the death probability of the wife/husband and all the variables are the same as before. For the survival probabilities, I use the mortality table provided by Superintendencia de Pensiones, the Chilean Pensions Supervisor, which consists of a period-table based on annuitant mortality data collected between 2008-2014. While for men, the data used for the construction of the tables also includes beneficiaries of annuities, this is not the case for women. This makes the mortality tables not consistent across gender and results in estimated prices that are lower for women than for men. ${ }^{11}$ Finally, in line with most other studies, I use the interest rates on central bank bonds as discount rates. Specifically, the data are obtained by the yield curve of indexed central bank bonds at 5-10 and 20 years. I increment the risk-free discount rate by $0.5 \mathrm{pp}$ to account for the higher returns obtained by the insurance companies from their investments.

An annuity is considered to be fairly priced when the MWR is equal to 1.

\subsection{Descriptive statistics}

Table 1 provides summary statistics on the characteristics of individuals included in my sample. The table shows that women represent $40 \%$ of the sample; pension savings, on average, amount to 102.000 dollars; and $79 \%$ of the individuals are old-age retirees, while $21 \%$ are early retirees. Moreover, married individuals represent $67 \%$ of the sample. Finally, the table shows that the majority of individuals rely on professional advice. Specifically, $24 \%$ of the people access the market directly, $43 \%$ through a sales agent, and 34\% through an independent financial advisor. This is explained by the fact that the annuity decision does not appear to be a simple task. SCOMP produces a 10 page-long report and the comparison about annuity

\footnotetext{
${ }^{11}$ Since the life expectancy of annuitants has been found to be higher than the average life expectancy in the population (Finkelstein and Poterba, 2004), the life expectancy's estimates for men are likely to be downward biased as beneficiaries might come from groups with a higher mortality risk.
} 
payments under different payout structures is not straightforward. Individuals seem to not have enough financial literacy to make this decision, and, as a result, they request the services of intermediaries. In Figure A.2, in the Appendix, I also report the share of individuals by channel for market access, in each decile of pension wealth, for women and men. The figure shows that as pension wealth increases, the share of individuals accessing the market through an advisor increases while the share of those entering through a sales agent decreases. No large differences exist across gender.

Table 2 provides summary statistics on annuity offers instead. Specifically, the table focuses on the initial annuity offers received by the individuals through the electronic market. The table shows that, on average, individuals receive offers from ten firms ${ }^{12}$ for each pension product they are willing to purchase. Since individuals, on average, request offers for 9 annuity products, they receive in total around 90 offers. ${ }^{13}$ Offers received for the same product differ only in terms of the monthly payout of the annuity and the risk-rating class of the firm, which ranges from $\mathrm{BB}+$ to $\mathrm{AA}+$. The average pension benefit of the monthly annuity offer is 604 dollars for men and 459 for women, which represents 5 and 4 percent, respectively, of their total pension wealth. The lower value for women is partially explained by their longer life horizon. The average price of the annuity offers turns out to be 0.03 for men and 0.06 for women. Figure A.4 analyses the average difference in the payout of the annuity between the offers that an individual receives for the same product. The annuity offers are ranked according to their monthly payout. The figure shows that, for instance, the 3rd highest offer is, on average, 1 percent point lower than the best offer received

Finally, Table 3 reports the summary statistics for the accepted offers. The table shows that, on average, the accepted offer is 1 percent higher than the initial offer made by the same firm (adjustment rate). ${ }^{14}$ Indeed, the average transaction price (payout) turns out to be lower (higher) than the average price (payout) of internal offers. ${ }^{15}$

\footnotetext{
${ }^{12}$ I observe 15 insurance companies on average per year. Overall, my sample includes 26 different insurance companies.

${ }^{13}$ A pension product is defined by a combination of guarantee periods, deferral periods, and share of wealth to annuitise. I focus only on immediate life annuities (no deferral period, no withdrawal ), which can differ in terms of the length of the guarantee period. Figure A.3, in the Appendix, shows how the number of offers received changes according to the pension wealth, age, and gender of the individual. Individuals with higher pension wealth as well as people close to the normal retirement age receive a relatively higher number of offers compared to lower wealth individuals. This is partially explained by the fact that it is costlier for a firm to service annuities that are slightly above the guaranteed minimum pension (GMP), as in the future, the MPG will rise above the annuity payment, and they will have to start conditioning with the government to transfer the top-up amount to the annuitant. As a result, fewer firms bid on low wealth annuitants (Illanes and Padi, 2019).

${ }^{14}$ Individuals, before accepting an offer, are allowed to negotiate outside the market with one of the insurance companies who had previously made an internal offer. As firms are not allowed to decrease their offers in this stage, most individuals negotiate contracts separately from SCOMP before accepting an annuity. In particular, $82.72 \%$ of men and $86.61 \%$ of women accept an offer that is made outside SCOMP.

15 This result, besides depending on the increases negotiated by the individuals on their initial offers, can
} 


\section{$3.3 \quad$ Key Facts}

Figure 1 analyses differences in the average transaction price across individuals accessing the market through the three different channels, separately for women and men. To make the sample of individuals more homogenous, the table focuses only on those who retire at the statutory age, which is 65 years for men and 60 for women. According to the table, men pay, on average, higher transaction prices than women. However, this is explained by the different construction of the mortality tables, which underestimate the life expectancy for men (see Section 3.1). Moreover, the figure shows that, for both sexes, those who access the market directly are those who pay, on average, the lowest price. This is partially due to the fact these people do not pay any commission, which is deducted from the individual's pension wealth before computing the payout of the annuity. Moreover, according to the figure, those who access the market through a sales agent have the highest average transaction price.

To understand the mechanism that drives this last result, in Figure 2, I analyse the characteristics of the firms from which individuals purchase the annuity, with respect to the rank of their initial offers. Specifically, as before, I rank all the offers that individuals receive through the electronic market for the same product. The annuity offers are ranked according to their monthly payout. The highest-ranked offer is the offer providing the highest monetary value (and the lowest price). The figure distinguishes people with respect to the channel for market access and gender. Interestingly, it shows that it is much more likely that an individual purchases the annuity from the firm that has offered the highest-payment initial offer when an advisor is involved in the process compared to the other two cases (sales agent, no intermediary). Among those who access the market through a sales agent, less than $20 \%$ of individuals purchase the offer from the firm that made the best internal offer. ${ }^{16}$ Again, no significant differences across gender exist.

This evidence can be explained by the different incentives of the two types of intermediaries (see Section 2); while advisors have an incentive to recommend the best annuity offer, the advice of sales agents is likely to be biased towards the offer made by their own company. Figure 3 confirms this hypothesis by reporting the share of those who access the market through an agent and accept the offer made by the sales agent's firm. The share turns out to be $90 \%$ for both women and men, suggesting a lack of competition among annuity providers when people access the market through a sales agent.

Finally, Figure 4 focuses only on those who access the market through a sales agent and looks specifically at the rank of the initial offer made by the sales agent's firm. The figure shows that the sales agent's firm does not make the best internal offer - its offer is likely to be the 6 th or 7 th highest offer. Moreover, for women, the distribution shifts to the right. This means that women receive, from the firm that is linked to their sales agent, even worse offers

\footnotetext{
be also related to composition effects.

${ }^{16}$ In Figure A.5, I also analyse the characteristics of the chosen firm with respect to the firm's risk-rating class.
} 
than men do.

\section{Conceptual Framework and Empirical Strategy}

\subsection{Conceptual Framework}

The existing literature provides evidence for gender-based price discrimination in markets where prices are determined through a negotiation process. Given the growing use of such markets, documenting this pattern is extremely important. So far, the literature seems to agree with the hypothesis that the observed discrimination is mostly driven by statistical inference about the reservation price distribution of buyers. Specifically, List (2004) shows that women's reservation prices are more dispersed than those of men. This makes profitable for dealers to offer women prices that are higher than men's ones and then negotiate with those who have lower reservation prices. This follows from dealers attempting to secure deals with high reservation value agents when selling their products.

List (2004) formalized this intuition as follows:

A buyer has a private reservation value $\mathrm{w}$, distributed according to $\mathrm{pdf} f(\mathrm{w})$ with a $\mathrm{CDF}$ $\mathrm{f}(\mathrm{w})$. The seller has marginal cost, c, and announces an initial price p. The seller's problem is therefore to maximize:

$$
(p-c) \operatorname{prob}(w \geq p)=(1-F(p)) ;
$$

which has the first-order condition of

$$
p=c+\frac{(1-F(P))}{f(p)}
$$

From the FOC follows that as $\mathrm{f}(\mathrm{p})$ decreases, namely, for more widespread distributions, $p$ increases. This means that if the women's reservation price distribution is more spread out than the men's one, profit-maximation by the seller leads to initial prices that are higher for women than for men.

If this is the case for the annuity market, annuity providers might have an incentive to practise gender-based price discrimination and offer women more unfairly priced annuities. But why should women have more dispersed reservation values than men in the annuity market? One hypothesis is that gender differences in reservation prices are driven by gender differences in financial literacy. We can assume that, in the annuity market, the reservation price depends on two factors: the individual's life expectancy and the individual's level of financial skills.

Formally, we can write this as follows:

$$
r=p+e
$$


where $\mathrm{r}$ is the reservation price, $\mathrm{p}$ is the actuarially fair price of an annuity, which depends on age and gender of the individual (which represent a proxy for the individual life expectancy), and e is an error term normally distributed with mean zero and variance $\sigma$, which is correlated with the individual's level of financial literacy. Most studies that measure financial literacy find that women are less literate than men (Lusardi and Mitchell, 2008) and that these differences in knowledge affect investment and annuitization decisions (Dwyer et al., 2002; Agnew et al., 2003). Given their lower level of financial skills, it is realistic to assume that women have, on average, more difficulties in computing the fair price of an annuity than have men. From this, it follows that the variance of the error term in the equation is higher for women than for men: $\sigma^{\mathrm{w}}{ }_{e}>\sigma^{\mathrm{m}}{ }_{e}$. Consequently, $\sigma^{\mathrm{w}}{ }_{r}>\sigma^{\mathrm{m}}{ }_{r}$. This suggests that women's reservation prices in the annuity market might exhibit higher dispersion compared to men's, and annuity providers might find it profitable to practise gender-based price discrimination.

\subsection{Empirical strategy}

I aim to test whether firms practise gender-based price discrimination in the annuity market and offer more unfairly priced annuities to women than they do to men. To do so, in this context, I cannot simply compare the value of annuity offers across gender, as women receive systematically lower offers given their longer life-expectancy. Although annuity prices, which are computed using gender-specific mortality tables, take into account gender differences in life expectancy (see Section 3.1), their estimates might remain biased due to other factors. The publicly available mortality tables are constructed using data from annuitants differentiating between women and men. However, while only one mortality table exists for men, which includes retirees who annuities their pension wealth and their beneficiaries, two distinct mortality tables exist for women- one for annuitants and one for beneficiaries. This makes the two tables inconsistent across gender. Moreover, the tables do not distinguish by marital status. If, for instance, differences in life expectancy by civil status for men are larger than the corresponding differences for women, this might affect the estimates of the annuity price differently by gender. Other factors that might bias the estimates are gender differences in life-expectancy improvements over time. ${ }^{17}$

I overcome this limitation by exploiting a particular feature of the Chilean annuity market, that is, the fact that people can access the annuity market through different channels, which are characterised by different levels of competition among firms. The data shows that most people accessing the market through a sales agent purchase an annuity from the sales agent's firm regardless of its price, which suggests a lack of competition among annuity providers. I claim that, if there is gender-based price discrimination in the market, it should be more

\footnotetext{
${ }^{17}$ There is evidence that during the last 50 years women have been characterized by a smaller improvement in their life expectancy compared to men (Oksuzyan et al., 2010; Thorslund et al., 2013). If mortality tables are not updated continuously or they are updated using an updating factor that does not differ by gender, this might result in biased estimations of the annuity prices. The price for women will be underestimated.
} 
pronounced when firms have some market power, namely, when people consult sales agents. ${ }^{18}$ Thus, my empirical strategy consists of comparing differences in transaction prices across channels separately for women and men. If firms tend to charge higher prices to women than to men, women consulting a sales agent should pay a mark-up on the price that is larger than that paid by their male counterparts. Consequently, larger differences in transaction prices across those who consult a sales agent and the remainder of individuals should be observed for women than for men.

However, differences in transaction prices might be also the result of the negotiation process. After receiving initial offers, individuals are allowed to enter a bargaining stage to try to negotiate a better price with one or more insurance companies who had previously made an internal offer through the electronic market. If women have worse negotiation skills than men, or if the behaviour of intermediaries vary across gender, this might lead to differences in transaction prices. To check this possibility, I use data on adjustment rates and test whether women consulting a sales agent are less successful at bargaining than other women. If yes, this would help to explain why they pay relatively higher transaction prices. ${ }^{19}$

The alternative hypothesis is that differences in final prices reflect differences in the value of offers received initially through SCOMP. Firms make initial offers using only the information transmitted by the individuals through the system (such as gender, age, municipality of residence, pension wealth, and beneficiaries). However, firms might use the gender of the individual to make some inference about other individual characteristics (for instance, the level of financial sophistication) and decide to set different pricing strategies across gender. By using data on initial offers, I test whether firms charge higher prices to people accessing the market through one of their sales agents and whether these markups are higher for women than for men. Since firms, initially, price annuities without any contact with the individual and individuals receive initial offers from most firms in the market, evidence for differences in initial prices across gender cannot be driven by selection or differences in bargaining abilities across individuals, but they are only consistent with gender-based price discrimination arising when there is a lack of competition in the market.

\section{Empirical Analysis}

\subsection{Transaction prices}

The first step of my analysis entails investigating differences in transaction prices across the three channels used to access the market separately for women and men. To do so, I specify

\footnotetext{
${ }^{18}$ This follows from the fact that some market power is necessary for price discrimination: if the competition is intense enough then there is little room for firms to price above marginal cost (Varian, 1989).

${ }^{19}$ The adjustment rate is defined as the percentage difference between the benefit payment of the accepted offer and the benefit payment of the initial offer made by the same firm (see Section 5.2).
} 
the reduced-form relationship between the transaction price and its determinants as follows:

$$
\begin{aligned}
\text { Price }_{i j k c n r t} & =\alpha+\varphi_{1} \text { Agent }_{j}+\varphi_{2} \text { NoInter }_{j}+\varphi_{3} \text { Product }_{k}+\varphi_{4} \text { NumCons }_{c}+ \\
& + \text { Year }_{t}+\text { Firm }_{n}+\text { Region }_{r}+\delta X_{i t}+\varepsilon_{i j k c n r t}
\end{aligned}
$$

where Agent $_{k}$ and NoIntermediary $k_{k}$ represent, respectively, dummies for those who access the channel through a sales agent and without any intermediary. The omitted category consists of those who consult an independent financial advisor, who, according to the descriptive statistics provided in Section 3.2, are those who obtain the lowest annuity prices. Moreover, Product $_{j}$ represents dummies for the type of pension product purchased and NunCons $c$ denotes dummies for the number of consultation. ${ }^{20} \mathrm{I}$ focus only on offers for immediate annuities, so products only differ in terms of the length of the guarantee period (see Footnote 9). I control for a vector of individual characteristics including pension wealth, age, dummy for the presence of beneficiaries, dummy for old age retirees and denotes it with $X_{i t}$. Finally, I include dummies for year, region and firm and indicate them with, respectively, Year , Region $_{r}$, Firm $_{n}$. In a further specification, by including two additional dummies, AgentFirm $i$ and OtherFirm I I divide those who access the market through a sales agent into two groups: those who accept the offer from the sales agent's firm and those who buy the annuity from a different firm.

I run the regression separately for women and men, as I want to allow the coefficients of all variables to differ by gender. This is motivated by the fact that, since women have a longer life expectancy compared to men and are less attached to the labour market, it is likely that firms attach lower weights to their pension wealth and age when they price annuities and try to predict the individual mortality risk. Similar differences might also exist for other covariates. The analysis thus focuses on within-gender differences across channels for market access. In order to make the coefficients comparable across subsamples, I present standardized coefficients. Finally, standard errors are clustered at the firm level.

The results are provided in Table 4. The table shows that old-age retirees, those with beneficiaries, and those purchasing a guaranteed period, pay relatively higher prices, which is in line with the existing literature (Finkelstein and Poterba, 2004). Moreover, those who access the market without any intermediary pay prices that are lower than those paid in the case of an intermediary. This is explained by the fact that since these individuals do not pay any commission (which is deducted from the individual's pension wealth), they pay relatively lower premium costs, conditional to the same amount of pension savings. Interestingly, the coefficient turns out to be lower for women than for men. What is more interesting is that, according to the table, women who consult a sales agent pay prices that are 0.144 sd higher than the prices paid by women who access the market through an independent financial advisor (column 2). Given an average transaction price of 0.04 (with sd 0.10), this represents a 30\% increase. This is not the case for men. The coefficient of the Agent ${ }_{j}$ dummy is not statistically

\footnotetext{
${ }^{20}$ People are allowed to go through the market three times with the same certificate of balance.
} 
significant in column 1 and appears much lower in magnitude. Finally, in columns 3 and 4, I report the result of the specification including the two additional dummies, AgentFirm $_{i}$ and OtherFirm ${ }_{i}$. Column 4 shows that the previous result is fully driven by those women who select the annuity offer made by the sales agent's firm. The coefficient of the AgentFirmi dummy is positive and statistically significant, while the coefficient of the OtherFirm dummy $_{j}$ is not statistically different from 0 . Among women consulting a sales agent, it is only those purchasing the annuity from the sales agent's firm who pay transaction prices that are higher than those paid by women consulting an independent financial advisor. Again, for men, the coefficients of both variables of interest are not statistically different from 0 (column 3).

\subsubsection{Heterogeneity}

I also explore how the effect varies with the amount of pension wealth accumulated by the individual and across municipalities with different average levels of education.

I run Equation 1 by subsamples of individuals that are defined according to the decile of pension wealth distribution they belong to. I distinguish women from men. The deciles are calculated using data from the entire population, so the cut-off points are the same for both sexes. In Figure 5, I report the coefficient of the Agent's Firm dummy. I find that while for men, the coefficient is not statistically significant, with some exceptions, in line with the previous results, for women, it is mostly significant and positive and seems to increase in magnitude as the pension wealth decreases. This suggests that the price increase charged from the sales agent's firm is higher for low-wealth women than for high-wealth women. Also, the fact that, for men, the coefficient is mostly zero regardless of the amount of pension savings excludes that gender differences in pension wealth or some other sorting mechanism are the channels behind my results.

Moreover, I collect data on the share of individuals with tertiary education at the municipal level from the Chilean National Institute of Statistics. By using the postal code of the individual's place of residence, I link each individual in my sample to the municipal-level data and generate a dummy variable for those individuals coming from highly educated municipalities using the 8th percentile of the education variable as the cut-off point. I then run Equation 1 including this new dummy variable (HighEdu), and its interactions with my three variables of interest (AgentFirm, OtherFirm, No Intermediary). ${ }^{21}$ In Figure 6, I plot the coefficient of the first interaction variable (AgentFirm*HighEdu), for women and for men. The figure shows that while for men the coefficient is not statistically different from 0 , for women, the level of education in the municipality of residence matters. Among women who purchase the annuity from the sales's agent firm, those coming from very highly educated municipalities pay a lower mark-up than others. In contrast, the coefficients of the other two interaction variables are not statistically significant for both women and men (these coefficients are not shown in the

\footnotetext{
${ }^{21}$ The 8 th percentile is equal to 0.27 , while the median and the sd are 0.18 and, respectively.
} 
table but are available upon request). This result reinforces the hypothesis that the role of the gender gap in education, presumably in financial education, explains the observed gender differences in transaction prices.

\subsection{Adjustment rates}

In this section, I investigate the channel behind my results. The first hypothesis is that differences in transaction prices across channels and gender might be the result of the negotiation process. Women with worse negotiation skills might have a preference for accessing the market through a sales agent, and, in turn, be more likely to pay higher transaction prices while this might not be the case for men. Moreover, the intermediary's behaviour during the negotiation might differ across gender.

To investigate this possibility, in the second step of my analysis, I investigate differences across gender and channels in increases that individuals negotiate on their initial offers. Specifically, for each accepted offer, I compute the adjustment rate, which is defined as the percentage difference in the benefit payment between the accepted and the initial offer, made by the same firm, to the same individual. Formally, the adjustment rate is defined as follows:

$$
\text { AdjustmentRate }_{\text {acc,scomp }}^{i j n}=\frac{\text { Payout }_{\text {acc }}^{i j n}-\text { Payout }_{\text {scomp }}^{i j n}}{\text { Payout }_{\text {scomp }}^{i j n}}
$$

where Payout $i_{\text {acc }}^{i j n}$ is the monthly benefit payment of the accepted offer made by firm $\mathrm{n}$ to individual i for product j, while Payout scomp $_{\text {ijn }}$ is the monthly benefit payment of the initial offer made through SCOMP by firm $n$ to individual i for product $j$.

I estimate Equation 1 and use the adjustment rate as dependent variable. This time, I also include dummies for the rank of the selected offer. ${ }^{22}$ This follows from the fact that firms making lower-ranked initial offers are more likely to concede higher adjustments. Thus, the inclusion of this set of dummies allows me to investigate differences in adjustment rates across channels conditional to selecting similar offers.

The estimates are reported in Table 5. Firstly, the table shows that individuals accessing the market directly receive higher increases on their initial offers compared to those who consult an intermediary. This result, which holds for all specifications, might be explained by the fact that, in the case of an intermediary, people pay a commission when they ask for an external offer. Since the external offer is net of commission and needs to be higher than the value of the initial offer, conditional to the same adjustment rate, external offers for those who do not pay any commission appear larger. Moreover, according to the table, those who access the market through a agent receive lower adjustment rates. Specifically, the coefficient of the Agent $_{i}$ dummy is negative for women and men, although it is statistically significant

\footnotetext{
${ }^{22}$ As explained in Section 3, I rank all the initial offers received through SCOMP by the same individual for the same pension product according to their monthly payout.
} 
only for the latter (columns 1-2). Interestingly, the results in columns 3-4 show that these results are mostly driven by those who purchase the annuity from the firm of the sales agent; they obtain adjustment rates that are $0.24 \mathrm{pp}$ lower than those obtained by the group of individuals consulting an advisor. This confirms the hypothesis that firms have market power when people consult one of their sales agents, and, consequently, are less willing to increase the value of their initial offers. However, the coefficient is similar in magnitude for women and men. ${ }^{23}$ This means that differences in adjustment rates cannot explain why it is only the women who access the market through a sales agent who pay higher transaction prices.

The alternative hypothesis is that differences in transaction prices reflect differences in initial prices and, precisely, that firms charge initially higher prices to women consulting one of their agents. As discussed in Section 2, this might be because firms believe women to have more dispersed reservation prices than men. If this is the case, those women with higher reservation prices should accept the offer without any negotiation, while women with lower reservation prices and who are aware of the unfairness of the offer should try to negotiate a better price. Consequently, I should observe that a group of women will obtain higher adjustment rates than their male counterparts.

To investigate this point, I proceed as follows. I run a quantile regression similar to my baseline regression. However, this time, I focus only on those who accept the offer from the sales agent's firm, and I do not include dummies for the rank of the initial offer. Moreover, I do not split the sample by gender but include a dummy for women. The quantile regression (10-50-90) results are presented in Table 6. The results show that when I do not control for the rank of the offer, women obtain higher adjustment rates than men (column 2). Moreover, the female marginal effect is not constant across the percentiles of payment adjustments but is higher at the top tail of the distribution- while the coefficient of female is close to 0 in column 1 , it becomes 0.23 in column 3 . This result suggests that the adjustment rate distribution of women exhibits higher variance than that of men and is consistent with the hypothesis that women have more dispersed reservation prices than men in the annuity market. ${ }^{24}$

\subsection{Initial Prices}

Overall, the findings of the previous section show that differences in transaction prices do not depend on gender differences in negotiation skills and, in turn, suggest that they might reflect differences in initial prices.

To explore this possibility, in this section, I analyse the prices of offers received, initially, through the electronic market. Firstly, I focus only on the initial prices of the accepted offers.

\footnotetext{
${ }^{23}$ I run the Wald test and, according to the test, I cannot reject the hypothesis of equality of two coefficients.

${ }^{24}$ This is also confirmed when I perform an F-Test on the residuals from OLS regressions in which adjustment rates are regressed on all explanatory variables included in the equation 1 . The F-test on the equality of variances rejects the null hypothesis of equal variances in favour of the alternative that women exhibit larger variance.
} 
Then, I extend my analysis to the entire sample of offers and individuals. I estimate the specification of the Equation 1 that includes the two additional dummies-AgentFirm $i$ and OtherFirm $_{i}$. The AgentFirm $i$ measures whether firms price annuities differently according to whether the individual has accessed the market through one of their sales agents or not. As in Section 5.2., I present standardized coefficients.

The first set of results are reported in Table 8, which focuses only on the initial prices of the accepted offers, and shows that the coefficient of the AgentFirm $i$ dummy is positive and statistically significant, again, only for women (columns 2 and 3). Moreover, the coefficient appears similar in magnitude to the estimate reported in Table 4. This confirms that when women access the market through a sales agent, the firm of the sales agent charges initial prices that are higher than those that the same firm offers to similar women accessing the market through one of the other two channels. Since those who consult a sales agent are likely to purchase the annuity from the sales agent's firm, the higher initial prices received by women translate into higher transaction prices.

In Table 9, I show the results of the same analysis, this time obtained using data on all initial offers. ${ }^{25}$ By extending the analysis to the entire sample of offers and individuals, I eliminate any selection bias arising from the choice of the annuity product and firm. Individuals receive initial offers through SCOMP from most firms in the market and before making any contact with these firms, which observe only the standard characteristics transmitted by the individual through the system. The results in columns 1 and 2 show that the coefficient of the AgentFirm $_{i}$ dummy is again significant and positive only for women. Moreover, in columns 3 and 4 , I focus only those who access the market though a sales agent and, by using individual fixed effects, analyse differences across offers within the same individual. The results show that individuals consulting a sales agent receive from the sales agent's firm annuity offers that are higher-priced compared to the offers made by the other firms in the market. This is the case for both women and men. However, the coefficient for women appears much larger than for men. The Wald test confirms that the coefficient is statistically different across the two subsamples.

\section{Discussion and Selection issues}

In this section, I discuss a range of concerns and selection issues that might bias my results.

The first concern might be that women accessing the market through a sales agent are different in some (unobserved) dimensions from those accessing the market directly or through an independent financial advisor. For instance, the three groups of women might differ in terms of bargaining skills. Women who are less able to negotiate, and, in turn, more likely to pay higher transaction prices, may have a preference for accessing the market through a sales

\footnotetext{
${ }^{25}$ I include also those individuals who do not accept any annuity product but opt for the program withdrawal option.
} 
agent. Such selection might be driving my results. However, the evidence provided in Section 5.2 shows that, on average, there are no differences in adjustment rates across channels. This excludes the fact that differences across channels in transaction prices are due to differences in the negotiation outcomes and, in turn, points to the role of initial prices in explaining my results.

A second concern might be related to the type of annuity product purchased. Women and men might have different preferences over annuity products. Women, for instance, who are found to be less risk-averse than men (Eckel and Grossman, 2008; Barsky et al., 1997; Levin et al., 1988), might be more likely to purchase annuity products with a longer guarantee period. If the markup charged by firms varies across annuity products, this might constitute a confounding factor. In my regression, I use fixed-effects for the type of pension product purchased, so I control for the fact that firms might systematically charge higher prices for specific products. However, it might also be the case that the product that gives the highest markup to the firm changes over time and that women, possibly, recommended by their sales agents, pick every time the highest-priced product, while men make different choices as they receive different advice. Although this would also represent a form of gender discrimination, in order to check that a different behaviour of sales agents across gender is not the main channel behind my results, I proceed as follows. I focus only on those who access the market through a sales agent and use data on all initial offers received by these individuals. I then estimate Equation 1 , this time, including a dummy for the initial offer of the accepted annuity (Accepted) and its interaction with AgentFirm (Accepted $*$ AgentFirm). This new interaction variable is my variable of interest, which tests whether the initial price of the annuities purchased from the sales agent's firm is statistically different from the price of the other annuity products offered by the same firm. The results are reported in Table 9. For women, the coefficient of the AgentFirm is still positive and statistically significant. This confirms the result of the previous section, specifically, the fact that the firm of the sales agent offers them higher prices than the other firms. Moreover, for women, also the coefficient of the Accepted dummy is statistically significant and negative. This suggests that, on average, the price of the accepted offers is lower than the average price of the rest of the offers. Women are selecting the best offers. Finally, the coefficient of the interaction term between this dummy and the Accepted dummy is not statistically different from zero. This means that the annuity products that women purchase from the firms of their sales agents are not priced differently by the other annuity products offered by the same firms. In other words, women do not pick, specifically, those annuities that are characterised by higher prices- all the products offered from the sales agent's firm are relatively more expensive. Instead, for men, the coefficients of all the three variables: AgentFirm, Accepted, Accepted $*$ AgentFirm are not statistically different from 0 instead. This evidence confirms that differences in the type of pension product purchased do not explain my results.

The concern of other selection issues is also addressed by providing evidence that the same 
differences observed for transaction prices exist for initial prices. Since in the analysis on initial prices I am looking at the entire population of individuals accessing the annuity market and firms make their initial offers without having any contact with the individuals, selection issues do not play any role here. Furthermore, differences in initial prices between the sales's agent firm and the other firms are also found when I include individual-fixed effects.

Overall, my results suggest that the fact that, only among women, those accessing the market through a sales agent pay higher transaction prices than others can be explained only by gender-based price discrimination, which arises because of a lack of competition among annuity providers.

\section{Conclusion}

In this paper, I study gender-based price discrimination in the annuity market. I use individuallevel data on all annuity offers made to Chilean retirees in the period 2004-2017. Since the benefit payments of an annuity depend on the individual's life expectancy, and there are important differences in the mortality risk across gender, it is not possible, in this context, to compare the monetary value or the price of annuities across gender in order to provide evidence for gender-based price discrimination. Thus, my empirical strategy exploits the fact that, in Chile, individuals can access the market through three different channels, which are characterised by different levels of competition among annuity providers. I claim that if there is gender price discrimination in the market, it should be more pronounced when firms have market power.

My results show that women who access the market through a sales agent, who is linked to a specific insurer, pay higher transaction prices than women who consult an independent financial advisor or no intermediary, while no significant differences in final prices across channels are found for men. These differences are not the result of the negotiation process but are rather driven by differences in initial prices -women consulting a sales agent receive initially higher-priced annuities from the sales agent's firm, while this is not the case for men. Overall, these findings are consistent with sellers' statistical inference about the buyer reservation price distribution. If women are believed to have more dispersed reservation prices, maybe because of their lower level of financial literacy, it can be profitable for firms to offer initial prices that are higher for women than for men in order to extract a rent from high-reservation value individuals. Of course, this sort of price discrimination is only possible when insurers have some market power. While advisors seem to help people to make better annuity choices, in the case of sales agents, the level of competition in the market is low and there is room for price discrimination.

There are several policy implications to draw from this analysis. Firstly, since there is evidence that women need to spend additional efforts to obtain a fair price, there may be a role for policy-makers to correct disparities and possibly eliminate this extra effort cost. 
Secondly, the data show that most individuals require the service of intermediaries, as they are not well informed about the pension system and do not have the financial literacy to make this kind of financial choice (Mitchell et al., 2009; Mitchell and Ruiz, 2009). The role of intermediaries in individuals' decision making should then be investigated and, possibly, better regulated, especially that of sales agents, as the initial evidence shows that they are not actually being helpful in assisting people in their choice and that the low level of competition in the market leaves room for price discrimination. 


\section{References}

Agnew, J., Balduzzi, P., and Sunden, A. (2003). Portfolio choice and trading in a large 401 (k) plan. American Economic Review, 93(1):193-215.

Alesina, A. F., Lotti, F., and Mistrulli, P. E. (2013). Do women pay more for credit? evidence from italy. Journal of the European Economic Association, 11(suppl_1):45-66.

Anagol, S., Cole, S., and Sarkar, S. (2017). Understanding the advice of commissions-motivated agents: Evidence from the indian life insurance market. Review of Economics and Statistics, 99(1):1-15.

Ayres, I. and Siegelman, P. (1995). Race and gender discrimination in bargaining for a new car. American Economic Review, pages 304-321.

Barsky, R. B., Juster, F. T., Kimball, M. S., and Shapiro, M. D. (1997). Preference parameters and behavioral heterogeneity: An experimental approach in the health and retirement study. The Quarterly Journal of Economics, 112(2):537-579.

Bucher-Koenen, T., Hackethal, A., Koenen, J., and Laudenbach, C. (2019). Do seemingly smarter people get better advice? Available at SSRN 2572961.

Dwyer, P. D., Gilkeson, J. H., and List, J. A. (2002). Gender differences in revealed risk taking: evidence from mutual fund investors. Economics Letters, 76(2):151-158.

Eckel, C. C. and Grossman, P. J. (2008). Men, women and risk aversion: Experimental evidence. Handbook of experimental economics results, 1:1061-1073.

Finkelstein, A. and Poterba, J. (2004). Adverse selection in insurance markets: Policyholder evidence from the uk annuity market. Journal of Political Economy, 112(1):183-208.

Fitzpatrick, A. (2017). Shopping while female: Who pays higher prices and why? American Economic Review, Papers and Proceedings, 107(5):146-49.

Gabaix, X. and Laibson, D. (2006). Shrouded attributes, consumer myopia, and information suppression in competitive markets. The Quarterly Journal of Economics, 121(2):505-540.

Georgarakos, D. and Inderst, R. (2014). Financial advice and stock market participation. Available at SSRN 1641302.

Goldberg, P. K. (1996). Dealer price discrimination in new car purchases: Evidence from the consumer expenditure survey. Journal of Political Economy, 104(3):622-654.

Illanes, G. and Padi, M. (2019). Retirement policy and annuity market equilibria: Evidence from chile. Technical report, National Bureau of Economic Research. 
Inderst, R. and Ottaviani, M. (2012). Competition through commissions and kickbacks. American Economic Review, 102(2):780-809.

Levin, I. P., Snyder, M. A., and Chapman, D. P. (1988). The interaction of experiential and situational factors and gender in a simulated risky decision-making task. The Journal of Psychology, 122(2):173-181.

List, J. A. (2004). The nature and extent of discrimination in the marketplace: Evidence from the field. The Quarterly Journal of Economics, 119(1):46-89.

Lusardi, A. and Mitchell, O. S. (2008). Planning and financial literacy: How do women fare? American Economic Review, 98(2):413-17.

Mitchell, O. S. and Ruiz, J. (2009). Pension payouts in chile: past, present, and future prospects. Pension Research Council WP, 7.

Mitchell, O. S., Todd, P., Bravo, D., and Lusardi, A. (2009). Learning from the chilean experience: The determinants of pension switching. Overcoming the saving slump: How to increase the effectiveness of financial education and saving programs, pages 301-23.

Oksuzyan, A., Crimmins, E., Saito, Y., O?Rand, A., Vaupel, J. W., and Christensen, K. (2010). Cross-national comparison of sex differences in health and mortality in denmark, japan and the us. European journal of epidemiology, 25(7):471-480.

Thorslund, M., Wastesson, J. W., Agahi, N., Lagergren, M., and Parker, M. G. (2013). The rise and fall of women?s advantage: a comparison of national trends in life expectancy at age 65 years. European journal of ageing, 10(4):271-277.

Varian, H. R. (1989). Price discrimination. Handbook of industrial organization, 1:597-654. 


\section{Figures and Tables}

Figure 1: The average transaction price by channel and gender

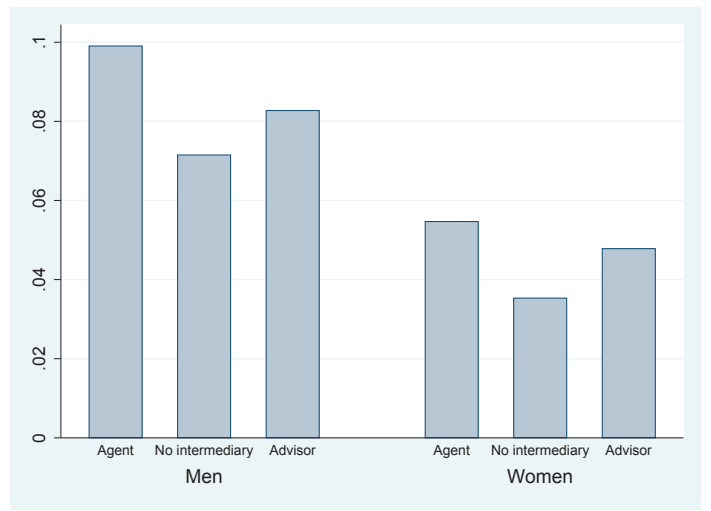

Note. The figure shows the average transaction price by channel for market access and gender. The price is defined as 1 - Money Worth Ratio (MWR), which is the discounted monetary value of the benefit payments of the annuity divided by the initial premium cost. To make the sample more homogenous, the figures is obtained using data for individuals at the statutory age (65 for men, 60 for women).

Figure 2: Characteristics of the firms making the accepted offer: Rank of their initial offer

(a) Men

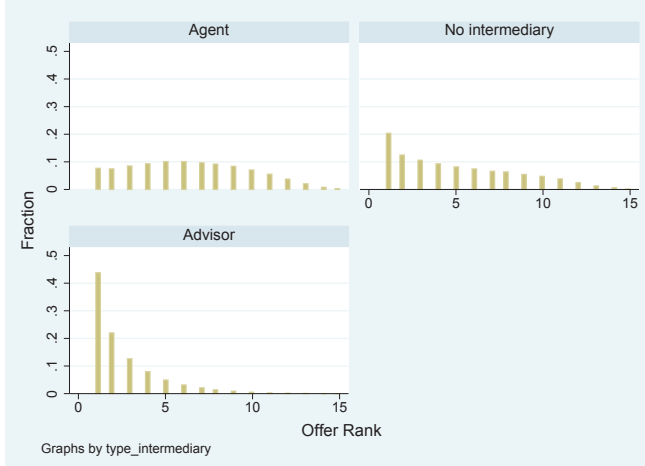

(b) Women

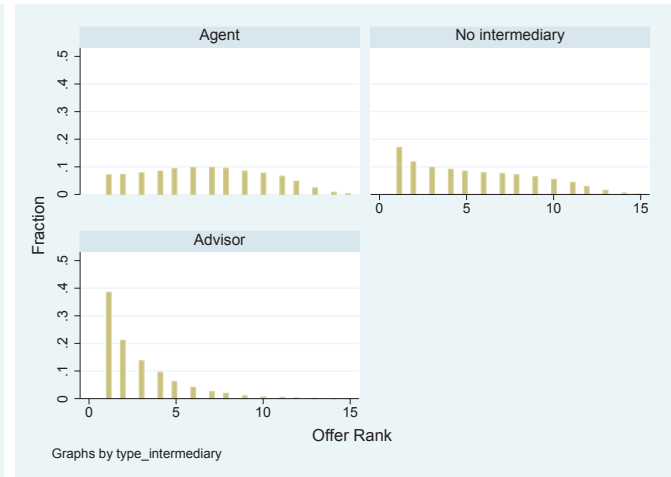

Note. The figure shows the share of individuals by the rank of the initial value of the accepted offer. Offers are ranked based on their monthly benefit payment. The lowest rank corresponds to the offer with the highest monetary value. 
Figure 3: Share of individuals accepting the offer from the sales agent's firm

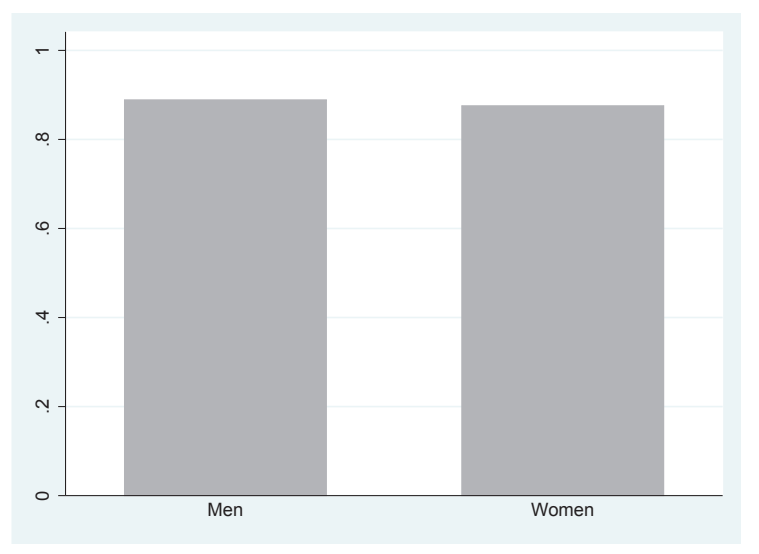

Note. The figure focuses only on those who access the market through a sales agent and shows the share of individuals purchasing the offer from the sales agent' firm.

Figure 4: Distribution of the rank of the offer made by the sales agent's firm

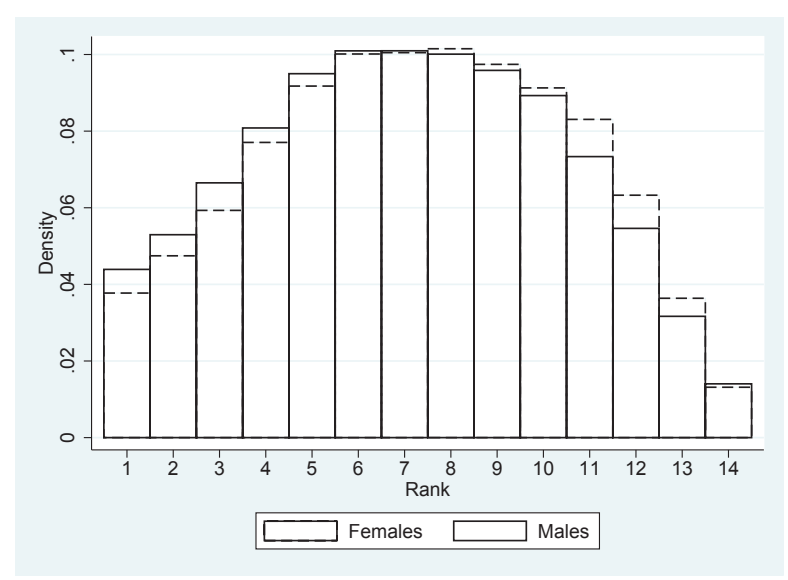

Note. The table shows the rank of the initial offer made by the sales agent's firm, for women and men. Annuity offers, received by the same individual, for the same annuity product, are ranked based on their monthly benefit payment. The lowest rank corresponds to the offer with the highest monetary value. The sample consists only of people accessing the market thought a sales agent. 
Figure 5: Heterogeneity: By Deciles of Pension Wealth.

(a) Men

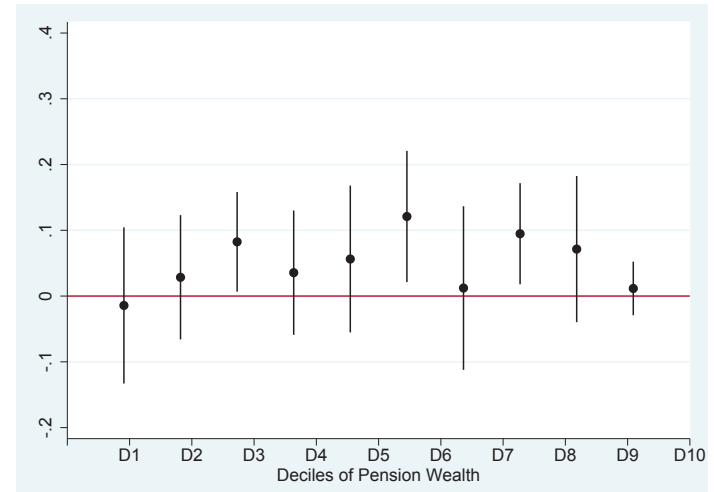

(b) Women

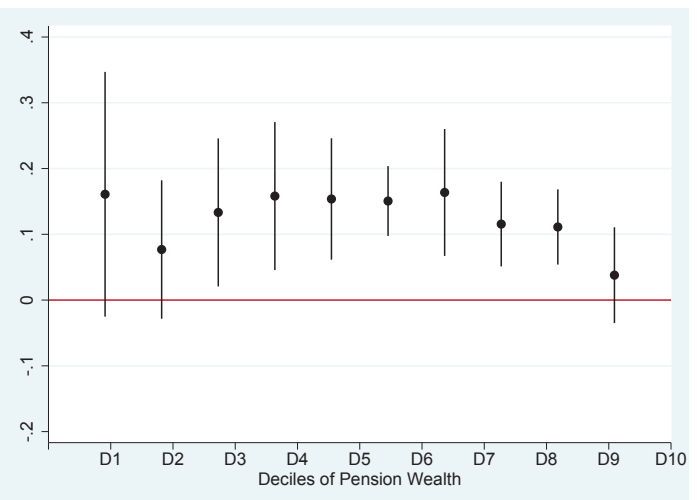

Note. The table shows the coefficients of the Agent's Firm dummy of Equation 1 by groups of individuals. Individuals are sorted according to the decile of the pension wealth distribution they belong to. The regression distinguishes women from men. Dependent Variable: Transaction Price. The deciles are calculated using data from the entire population, so the cut-off points are the same for women and men.

Figure 6: Heterogeneity: By Municipal Education Level.

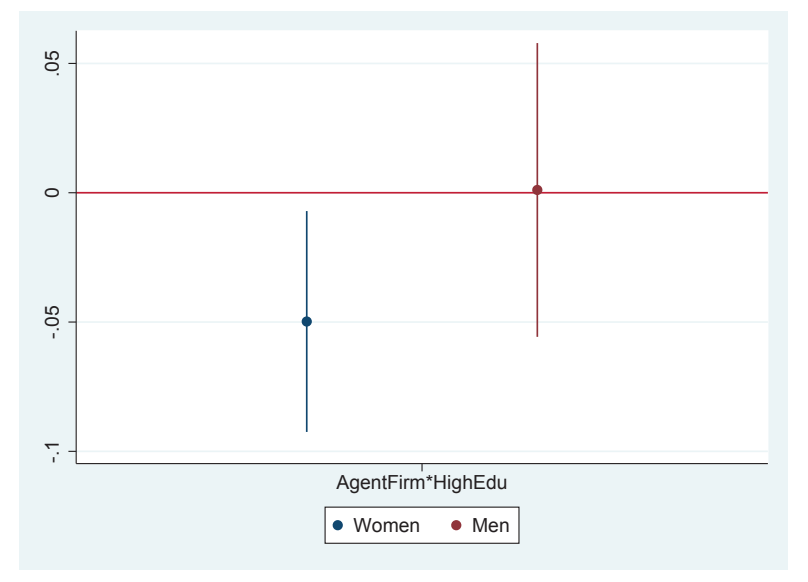

Note. The table shows the coefficients of the interaction variables AgentFirm*HighEdu included in Equation 1. HighEdu is a dummy variable for individuals coming from highly educated municipalities. The regression distinguishes women from men. Dependent Variable: Transaction Price. 
Table 1: Summary statistics: Individuals in the sample

\begin{tabular}{lrrr}
\hline Variable & Mean & Sd & Number individuals \\
\hline Female & 0.38 & 0.49 & 334,574 \\
Age & 63.08 & 3.93 & 334,574 \\
Savings & 102557 & 79134.97 & 334,574 \\
Married & 0.67 & 0.47 & 334,574 \\
Beneficiaries & 0.02 & 0.16 & 334,574 \\
Old-Age Retirees & 0.79 & 0.41 & 334,574 \\
\hline Channel: Indip. Financial advisor & 0.34 & 0.47 & 334,574 \\
Channel: Sales Agent & 0.42 & 0.49 & 334,574 \\
Channel: No Intermediary & 0.24 & 0.43 & 334,574 \\
\hline
\end{tabular}

Notes. Beneficiaries as well as those entitled to disability pension are excluded from the sample. Pension savings are expressed in US dollars using a CLP/USD exchange rate equal to 41,24. 
Table 2: Summary statistics: (Initial) Annuity offers

\begin{tabular}{llrrr}
\hline & & Mean & Sd & N \\
\hline N Offers & Men & 10.5791 & 2.9255 & 207,226 \\
N Offers & Women & 11.0246 & 2.7764 & 127,343 \\
N Offers & Total & 10.7487 & 2.8778 & 334,569 \\
\hline Average Payout & Men & 604.9987 & 463.3083 & $9,660,059$ \\
Average Payout & Women & 459.7721 & 264.1238 & $6,477,954$ \\
Average Payout & Total & 546.7033 & 401.9461 & $16,138,013$ \\
\hline Payout/Savings & Men & 5.0392 & 1.0493 & $9,660,059$ \\
Payout/Savings & Women & 4.4003 & 0.5562 & $6,477,954$ \\
Payout/Savings & Total & 4.7827 & 0.9388 & $16,138,013$ \\
\hline Price & MenMen & 0.0346 & 0.2007 & $9,660,059$ \\
Price & Women & 0.0632 & 0.0922 & $6,477,954$ \\
Price & Total & 0.0461 & 0.1665 & $16,138,013$ \\
\hline
\end{tabular}

Notes. The table shows the mean, the standard deviation and the number of observations for the following variables: number of offers received by an individual for a specific pension product, monthly payout, ratio between the monthly payout of the annuity and the individual pension wealth (in percent), and the price of the annuities. Payouts are expressed in US dollars. The tables focuses only on annuity offers made through the electronic market. 
Table 3: Summary Statistics: Accepted Annuity Offers

\begin{tabular}{llrrr}
\hline & & Mean & Sd & N \\
\hline Payout & MenMen & 503.9033 & 427.7759 & 70,486 \\
Payout & Women & 428.3286 & 273.6497 & 46,971 \\
Payout & Total & 473.6810 & 375.6721 & 117,457 \\
\hline Adj Rate & Men & 0.0144 & 0.0161 & 60,100 \\
Adj Rate & Women & 0.0167 & 0.0172 & 40,653 \\
Adj Rate & Total & 0.0153 & 0.0166 & 100,753 \\
\hline Price & Men & 0.0077 & 0.2356 & 70,486 \\
Price & Women & 0.0409 & 0.1086 & 46,971 \\
Price & Total & 0.0117 & 0.1964 & 117,457 \\
\hline
\end{tabular}

Notes. The table shows the average, the standard deviation and the number of the observations for the following variables: the monthly payout, the percentage increase in the payout negotiated outside SCOMP, the price of annuities. Payouts are expressed in US dollars. The table focuses only on accepted offers. 
Table 4: Transaction Prices

\begin{tabular}{|c|c|c|c|c|}
\hline & $\begin{array}{c}(1) \\
\text { Males }\end{array}$ & $\begin{array}{c}(2) \\
\text { Females }\end{array}$ & $\begin{array}{c}(3) \\
\text { Males }\end{array}$ & $\begin{array}{c}(4) \\
\text { Females }\end{array}$ \\
\hline Agent & $\begin{array}{c}0.046 \\
(0.030)\end{array}$ & $\begin{array}{c}0.128^{* * *} \\
(0.022)\end{array}$ & & \\
\hline Agent: Agent's Firm & & & $\begin{array}{c}0.049 \\
(0.031)\end{array}$ & $\begin{array}{c}0.144^{* * *} \\
(0.021)\end{array}$ \\
\hline Agent: Other Firm & & & $\begin{array}{c}0.028 \\
(0.029)\end{array}$ & $\begin{array}{c}0.047 \\
(0.049)\end{array}$ \\
\hline No Intermediary & $\begin{array}{c}-0.063^{* *} \\
(0.025)\end{array}$ & $\begin{array}{c}-0.056^{* *} \\
(0.025)\end{array}$ & $\begin{array}{c}-0.062^{* *} \\
(0.025)\end{array}$ & $\begin{array}{c}-0.054^{* *} \\
(0.024)\end{array}$ \\
\hline Married & $\begin{array}{c}-0.124^{* * *} \\
(0.017)\end{array}$ & $\begin{array}{c}-0.246^{* * *} \\
(0.008)\end{array}$ & $\begin{array}{c}-0.124^{* * *} \\
(0.017)\end{array}$ & $\begin{array}{c}-0.246^{* * *} \\
(0.007)\end{array}$ \\
\hline Old Age Retirees & $\begin{array}{c}1.724^{* * *} \\
(0.070)\end{array}$ & $\begin{array}{c}2.770^{* * *} \\
(0.163)\end{array}$ & $\begin{array}{c}1.723^{* * *} \\
(0.070)\end{array}$ & $\begin{array}{c}2.770^{* * *} * \\
(0.163)\end{array}$ \\
\hline Beneficiaries $=1$ & $\begin{array}{c}0.416^{* * *} \\
(0.020)\end{array}$ & $\begin{array}{c}0.418^{* * *} \\
(0.090)\end{array}$ & $\begin{array}{c}0.416^{* * *} \\
(0.020)\end{array}$ & $\begin{array}{c}0.416^{* * * *} \\
(0.090)\end{array}$ \\
\hline Age & $\begin{array}{c}-0.599 * * * \\
(0.031)\end{array}$ & $\begin{array}{l}-0.146 \\
(0.091)\end{array}$ & $\begin{array}{c}-0.599^{* * *} \\
(0.031)\end{array}$ & $\begin{array}{l}-0.145 \\
(0.091)\end{array}$ \\
\hline Age 2 & $\begin{array}{c}0.005^{* * *} \\
(0.000)\end{array}$ & $\begin{array}{c}0.001^{* *} \\
(0.001)\end{array}$ & $\begin{array}{c}0.005^{* * *} \\
(0.000)\end{array}$ & $\begin{array}{c}0.001^{* *} \\
(0.001)\end{array}$ \\
\hline Pension Savings & $\begin{array}{c}0.006^{* * *} \\
(0.001)\end{array}$ & $\begin{array}{c}0.003^{* * *} \\
(0.001)\end{array}$ & $\begin{array}{c}0.006^{* * *} \\
(0.001)\end{array}$ & $\begin{array}{c}0.003^{* * *} \\
(0.001)\end{array}$ \\
\hline Pension Savings 2 & $\begin{array}{c}-0.000^{* * *} \\
(0.000)\end{array}$ & $\begin{array}{c}-0.000^{* * *} \\
(0.000)\end{array}$ & $\begin{array}{c}-0.000^{* * *} \\
(0.000)\end{array}$ & $\begin{array}{c}-0.000^{* * * *} \\
(0.000)\end{array}$ \\
\hline $\mathrm{N}$ Consultation $=2$ & $\begin{array}{l}-0.015 \\
(0.010)\end{array}$ & $\begin{array}{l}-0.013 \\
(0.007)\end{array}$ & $\begin{array}{l}-0.014 \\
(0.010)\end{array}$ & $\begin{array}{l}-0.009 \\
(0.007)\end{array}$ \\
\hline $\mathrm{N}$ Consultation $=3$ & $\begin{array}{c}-0.066^{* *} \\
(0.027)\end{array}$ & $\begin{array}{c}-0.118^{* * *} \\
(0.022)\end{array}$ & $\begin{array}{c}-0.065^{* *} \\
(0.028)\end{array}$ & $\begin{array}{c}-0.114^{* * *} \\
(0.023)\end{array}$ \\
\hline Guaranteed Months $=60$ & $\begin{array}{c}0.025 \\
(0.039)\end{array}$ & $\begin{array}{c}0.148^{* * *} \\
(0.047)\end{array}$ & $\begin{array}{c}0.026 \\
(0.039)\end{array}$ & $\begin{array}{c}0.149^{* * *} * \\
(0.047)\end{array}$ \\
\hline Guaranteed Months $=120$ & $\begin{array}{c}0.098^{* * *} \\
(0.011)\end{array}$ & $\begin{array}{c}0.097^{* * *} \\
(0.014)\end{array}$ & $\begin{array}{c}0.098^{* * *} \\
(0.011)\end{array}$ & $\begin{array}{c}0.097^{* * * *} \\
(0.013)\end{array}$ \\
\hline Guaranteed Months $=180$ & $\begin{array}{c}0.196^{* * *} \\
(0.014)\end{array}$ & $\begin{array}{c}0.231^{* * *} \\
(0.016)\end{array}$ & $\begin{array}{c}0.195 * * * \\
(0.014)\end{array}$ & $\begin{array}{c}0.229 * * * \\
(0.016)\end{array}$ \\
\hline Guaranteed Months $=240$ & $\begin{array}{c}0.333^{* * *} \\
(0.016)\end{array}$ & $\begin{array}{c}0.391 * * * \\
(0.015)\end{array}$ & $\begin{array}{c}0.332^{* * *} \\
(0.016)\end{array}$ & $\begin{array}{c}0.389^{* * *} * \\
(0.015)\end{array}$ \\
\hline Guaranteed Months $=360$ & $\begin{array}{c}0.550^{* * *} \\
(0.058)\end{array}$ & $\begin{array}{c}0.595^{* * *} \\
(0.035)\end{array}$ & $\begin{array}{c}0.549^{* * *} \\
(0.059)\end{array}$ & $\begin{array}{c}0.590 * * * \\
(0.036)\end{array}$ \\
\hline Observations & 62,744 & 42,316 & 62,744 & 42,316 \\
\hline R-squared & 0.523 & 0.481 & 0.523 & 0.482 \\
\hline Year FE & YES & YES & YES & YES \\
\hline Firm FE & YES & YES & YES & YES \\
\hline Region FE & YES & YES & YES & YES \\
\hline
\end{tabular}

Note. Dependent variables: Transaction prices. Standardized coefficients. Financial advisor, no beneficiary, early retirees, guaranteed months $=0$ and consultation $=1$ are the omitted categories. Robust standard errors clustered at the firm level in parentheses. ${ }^{* * *} \mathrm{p}<0.01,{ }^{* *} \mathrm{p}<0.05,{ }^{*} \mathrm{p}<0.1$ 
Table 5: Adjustment rates, Accepted Offers

\begin{tabular}{|c|c|c|c|c|}
\hline & $\begin{array}{c}(1) \\
\text { Males }\end{array}$ & $\begin{array}{c}(2) \\
\text { Females }\end{array}$ & $\begin{array}{c}(3) \\
\text { Males }\end{array}$ & $\begin{array}{c}(4) \\
\text { Females }\end{array}$ \\
\hline Agent & $\begin{array}{c}-0.191 * * \\
(0.092)\end{array}$ & $\begin{array}{l}-0.185 \\
(0.117)\end{array}$ & & \\
\hline Agent: Agent'Firm & & & $\begin{array}{c}-0.244^{* *} \\
(0.098)\end{array}$ & $\begin{array}{c}-0.245^{*} \\
(0.119)\end{array}$ \\
\hline Agent: Other Firm & & & $\begin{array}{c}0.003 \\
(0.077)\end{array}$ & $\begin{array}{c}0.035 \\
(0.118)\end{array}$ \\
\hline No intermediary & $\begin{array}{c}1.315^{* * *} \\
(0.076)\end{array}$ & $\begin{array}{c}1.454^{* * *} \\
(0.118)\end{array}$ & $\begin{array}{c}1.299^{* * *} \\
(0.078)\end{array}$ & $\begin{array}{c}1.438^{* * *} \\
(0.118)\end{array}$ \\
\hline Married & $\begin{array}{c}0.094^{* * *} \\
(0.027)\end{array}$ & $\begin{array}{c}0.037 \\
(0.024)\end{array}$ & $\begin{array}{c}0.092^{* * *} \\
(0.027)\end{array}$ & $\begin{array}{c}0.035 \\
(0.023)\end{array}$ \\
\hline Old Age Retirees & $\begin{array}{l}-0.013 \\
(0.032)\end{array}$ & $\begin{array}{l}-0.032 \\
(0.040)\end{array}$ & & \\
\hline Beneficiaries = 1 & $\begin{array}{c}0.049 \\
(0.036)\end{array}$ & $\begin{array}{l}-0.058 \\
(0.086)\end{array}$ & $\begin{array}{c}0.047 \\
(0.036)\end{array}$ & $\begin{array}{l}-0.052 \\
(0.087)\end{array}$ \\
\hline Age & $\begin{array}{c}-0.075^{* * *} \\
(0.021)\end{array}$ & $\begin{array}{l}-0.008 \\
(0.058)\end{array}$ & $\begin{array}{c}-0.075^{* * *} \\
(0.021)\end{array}$ & $\begin{array}{l}-0.027 \\
(0.048)\end{array}$ \\
\hline Age2 & $\begin{array}{c}0.001^{* * *} \\
(0.000)\end{array}$ & $\begin{array}{c}0.000 \\
(0.000)\end{array}$ & $\begin{array}{c}0.001^{* * *} \\
(0.000)\end{array}$ & $\begin{array}{c}0.000 \\
(0.000)\end{array}$ \\
\hline Pen Savings & $\begin{array}{l}-0.001 \\
(0.001)\end{array}$ & $\begin{array}{c}-0.003^{* *} \\
(0.001)\end{array}$ & $\begin{array}{l}-0.001 \\
(0.001)\end{array}$ & $\begin{array}{c}-0.003^{* *} \\
(0.001)\end{array}$ \\
\hline Pen Savings 2 & $\begin{array}{l}-0.000 \\
(0.000)\end{array}$ & $\begin{array}{c}0.000 \\
(0.000)\end{array}$ & $\begin{array}{l}-0.000 \\
(0.000)\end{array}$ & $\begin{array}{c}0.000 \\
(0.000)\end{array}$ \\
\hline $\mathrm{N}$ consultation $=2$ & $\begin{array}{c}0.161^{* * *} \\
(0.024)\end{array}$ & $\begin{array}{c}0.156^{* * *} \\
(0.023)\end{array}$ & $\begin{array}{c}0.155^{* * *} \\
(0.023)\end{array}$ & $\begin{array}{c}0.147^{* * *} \\
(0.021)\end{array}$ \\
\hline $\mathrm{N}$ consultation $=3$ & $\begin{array}{c}0.197^{* * *} \\
(0.052)\end{array}$ & $\begin{array}{c}0.272^{* * *} \\
(0.056)\end{array}$ & $\begin{array}{c}0.186^{* * *} \\
(0.051)\end{array}$ & $\begin{array}{c}0.257^{* * *} \\
(0.053)\end{array}$ \\
\hline Guaranteed Months $=60$ & $\begin{array}{c}-0.123^{* *} \\
(0.058)\end{array}$ & $\begin{array}{l}-0.077 \\
(0.085)\end{array}$ & $\begin{array}{c}-0.129^{* *} \\
(0.058)\end{array}$ & $\begin{array}{l}-0.077 \\
(0.087)\end{array}$ \\
\hline Guaranteed Months $=120$ & $\begin{array}{c}-0.117^{* * *} \\
(0.018)\end{array}$ & $\begin{array}{c}-0.082^{* * *} \\
(0.018)\end{array}$ & $\begin{array}{c}-0.113^{* * *} \\
(0.018)\end{array}$ & $\begin{array}{c}-0.080^{* * *} \\
(0.019)\end{array}$ \\
\hline Guaranteed Months $=180$ & $\begin{array}{c}-0.119^{* * *} \\
(0.026)\end{array}$ & $\begin{array}{c}-0.091 * * * \\
(0.018)\end{array}$ & $\begin{array}{c}-0.114^{* * *} \\
(0.025)\end{array}$ & $\begin{array}{c}-0.088^{* * *} * \\
(0.018)\end{array}$ \\
\hline Guaranteed Months $=240$ & $\begin{array}{c}-0.062^{*} \\
(0.034)\end{array}$ & $\begin{array}{c}-0.088^{* * *} \\
(0.027)\end{array}$ & $\begin{array}{l}-0.056 \\
(0.034)\end{array}$ & $\begin{array}{c}-0.084^{* * *} \\
(0.027)\end{array}$ \\
\hline Guaranteed Months $=360$ & $\begin{array}{c}0.064 \\
(0.088)\end{array}$ & $\begin{array}{c}0.078 \\
(0.083)\end{array}$ & $\begin{array}{c}0.081 \\
(0.090)\end{array}$ & $\begin{array}{c}0.096 \\
(0.082)\end{array}$ \\
\hline Observations & 60,090 & 40,644 & 60,090 & 40,644 \\
\hline R-squared & 0.251 & 0.286 & 0.252 & 0.287 \\
\hline Year FE & YES & YES & YES & YES \\
\hline Rank FE & NO & NO & NO & NO \\
\hline Firm FE & YES & YES & YES & YES \\
\hline Region FE & YES & YES & YES & YES \\
\hline
\end{tabular}

Note: The dependent variables is the adjustment rate in the benefit payment between the accepted external offer and the initial offer made by the same firm to the same individual. Financial advisor, no beneficiary and early retirees are the omitted categories. Other controls include dummies for the length of the guarantee period purchased and for the number of the consultation. Robust standard errors clustered at the firm level in parentheses. 
Table 6: Adjustment rates, Accepted Offers, Quantile regressions

\begin{tabular}{|c|c|c|c|}
\hline VARIABLES & $\begin{array}{c}(1) \\
20 \mathrm{Q}\end{array}$ & $\begin{array}{c}(2) \\
50 \mathrm{Q} \\
\end{array}$ & $\begin{array}{c}3) \\
80 \mathrm{Q}\end{array}$ \\
\hline Female & $\begin{array}{c}0.040^{* * *} \\
(0.016)\end{array}$ & $\begin{array}{c}0.074^{* *} \\
(0.032)\end{array}$ & $\begin{array}{c}0.233^{* * *} \\
(0.047)\end{array}$ \\
\hline Married & $\begin{array}{c}0.036^{* * *} \\
(0.010)\end{array}$ & $\begin{array}{c}0.060^{* * *} \\
(0.020)\end{array}$ & $\begin{array}{c}0.094^{* * * *} \\
(0.032)\end{array}$ \\
\hline Age & $\begin{array}{c}0.012 \\
(0.008)\end{array}$ & $\begin{array}{c}-0.004 \\
(0.040)\end{array}$ & $\begin{array}{c}0.051 \\
(0.068)\end{array}$ \\
\hline Age 2 & $\begin{array}{l}-0.000^{*} \\
(0.000)\end{array}$ & $\begin{array}{c}0.000 \\
(0.000)\end{array}$ & $\begin{array}{l}-0.000 \\
(0.001)\end{array}$ \\
\hline Penion Savings & $\begin{array}{c}0.001 \\
(0.001)\end{array}$ & $\begin{array}{c}0.003^{* * * *} \\
(0.001)\end{array}$ & $\begin{array}{c}0.004^{* * *} \\
(0.001)\end{array}$ \\
\hline Pension Savings 2 & $\begin{array}{l}-0.000 \\
(0.000)\end{array}$ & $\begin{array}{c}-0.000^{* * *} \\
(0.000)\end{array}$ & $\begin{array}{c}-0.000^{* * *} \\
(0.000)\end{array}$ \\
\hline $\mathrm{N}$ consultation $=2$ & $\begin{array}{c}0.025^{* * *} \\
(0.012)\end{array}$ & $\begin{array}{c}0.136^{* * *} * \\
(0.036)\end{array}$ & $\begin{array}{c}0.324^{* * *} \\
(0.041)\end{array}$ \\
\hline $\mathrm{N}$ consultation $=3$ & $\begin{array}{c}0.057^{* * *} * \\
(0.014)\end{array}$ & $\begin{array}{c}0.162^{* * *} \\
(0.045)\end{array}$ & $\begin{array}{c}0.437^{* * *} * \\
(0.093)\end{array}$ \\
\hline Guaranteed Months $=60$ & $\begin{array}{c}-0.073 \\
(0.061)\end{array}$ & $\begin{array}{c}-0.144^{* * *} \\
(0.045)\end{array}$ & $\begin{array}{c}-0.230^{* *} \\
(0.093)\end{array}$ \\
\hline Guaranteed Months $=120$ & $\begin{array}{c}-0.017^{* * *} \\
(0.011)\end{array}$ & $\begin{array}{c}-0.076^{* * *} \\
(0.033)\end{array}$ & $\begin{array}{c}-0.162^{\text {*** }}(0.043)\end{array}$ \\
\hline Guaranteed Months $=180$ & $\begin{array}{c}-0.018^{* * * *} \\
(0.013)\end{array}$ & $\begin{array}{c}-0.071^{* * *} \\
(0.027)\end{array}$ & $\begin{array}{c}-0.151^{* * *} \\
(0.026)\end{array}$ \\
\hline Guaranteed Months $=240$ & $\begin{array}{c}-0.022^{* * * *} \\
(0.023)\end{array}$ & $\begin{array}{l}-0.056 \\
(0.042)\end{array}$ & $\begin{array}{c}-0.146^{* * *} \\
(0.070)\end{array}$ \\
\hline Guaranteed Months $=360$ & $\begin{array}{c}0.035 \\
(0.066)\end{array}$ & $\begin{array}{l}-0.026 \\
(0.092)\end{array}$ & $\begin{array}{c}-179 \\
(0.12)\end{array}$ \\
\hline Observations & 39,895 & 39,895 & 39,895 \\
\hline R-squared & 0.136 & 0.152 & 0.155 \\
\hline Year FE & YES & YES & YES \\
\hline Firm FE & YES & YES & YES \\
\hline Region FE & YES & YES & YES \\
\hline Rank FE & YES & YES & YES \\
\hline
\end{tabular}

Note: The dependent variables is the adjustment rate in the benefit payment between the accepted external offer and initial offers made by the same firm to the same individual $(* 100)$. Sample: Individuals purchasing the annuity from the sales agent's firm. Financial advisor, no beneficiary, early retirees, guaranteed months $=0$ and consultation $=1$ are the omitted categories. Robust standard errors clustered at the firm level in parentheses. 
Table 7: Initial Prices, Accepted Offers

\begin{tabular}{|c|c|c|c|c|}
\hline & $\begin{array}{c}(1) \\
\text { Males }\end{array}$ & $\begin{array}{c}(2) \\
\text { Females }\end{array}$ & $\begin{array}{c}(3) \\
\text { Males }\end{array}$ & $\begin{array}{c}(4) \\
\text { Females }\end{array}$ \\
\hline Agent & $\begin{array}{c}0.0438 \\
(0.0271)\end{array}$ & $\begin{array}{c}0.1155^{* * *} \\
(0.0155)\end{array}$ & & \\
\hline Agent: Agent's Firm & & & $\begin{array}{c}0.0463 \\
(0.0279)\end{array}$ & $\begin{array}{c}0.1292^{* * *} \\
(0.0155)\end{array}$ \\
\hline Agent: Other Firm & & & $\begin{array}{c}0.0301 \\
(0.0266)\end{array}$ & $\begin{array}{c}0.0471 \\
(0.0421)\end{array}$ \\
\hline No Intermediary & $\begin{array}{l}-0.0227 \\
(0.0229)\end{array}$ & $\begin{array}{c}0.0304^{* * *} \\
(0.0087)\end{array}$ & $\begin{array}{l}-0.0222 \\
(0.0230)\end{array}$ & $\begin{array}{c}0.0325^{* * *} \\
(0.0081)\end{array}$ \\
\hline Married & $\begin{array}{c}-0.1184^{* * *} \\
(0.0177)\end{array}$ & $\begin{array}{c}-0.2429 * * * \\
(0.0084)\end{array}$ & $\begin{array}{c}-0.1182^{* * *} \\
(0.0176)\end{array}$ & $\begin{array}{c}-0.2426^{* * *} \\
(0.0081)\end{array}$ \\
\hline Old Age Retirees & $\begin{array}{c}1.7054^{* * *} * \\
(0.0695)\end{array}$ & $\begin{array}{c}2.7378^{* * *} \\
(0.1596)\end{array}$ & $\begin{array}{c}1.7053^{* * *} \\
(0.0695)\end{array}$ & $\begin{array}{c}2.7371^{\text {*** }} \\
(0.1600)\end{array}$ \\
\hline Beneficiaries = 1 & $\begin{array}{c}0.4066^{* * *} \\
(0.0211)\end{array}$ & $\begin{array}{c}0.3991^{* * * *} \\
(0.0826)\end{array}$ & $\begin{array}{c}0.4068^{* * *} \\
(0.0211)\end{array}$ & $\begin{array}{c}0.3970^{* * * *} \\
(0.0826)\end{array}$ \\
\hline Age & $\begin{array}{c}-0.5914^{* * *} \\
(0.0324)\end{array}$ & $\begin{array}{l}-0.1365 \\
(0.0891)\end{array}$ & $\begin{array}{c}-0.5914^{* * *} \\
(0.0324)\end{array}$ & $\begin{array}{l}-0.1358 \\
(0.0891)\end{array}$ \\
\hline Age2 & $\begin{array}{c}0.0048^{* * *} \\
(0.0003)\end{array}$ & $\begin{array}{l}0.0014^{*} \\
(0.0007)\end{array}$ & $\begin{array}{c}0.0048^{* * *} \\
(0.0003)\end{array}$ & $\begin{array}{c}0.0014^{*} \\
(0.0007)\end{array}$ \\
\hline Pension Savings & $\begin{array}{c}0.0060^{* * *} \\
(0.0008)\end{array}$ & $\begin{array}{c}0.0033^{* * *} \\
(0.0009)\end{array}$ & $\begin{array}{c}0.0060^{* * *} \\
(0.0008)\end{array}$ & $\begin{array}{c}0.0033^{* * *} \\
(0.0009)\end{array}$ \\
\hline Pension Savings 2 & $\begin{array}{c}-0.0000^{* * * *} \\
(0.0000)\end{array}$ & $\begin{array}{c}-0.0000 * * * \\
(0.0000)\end{array}$ & $\begin{array}{c}-0.0000 * * * \\
(0.0000)\end{array}$ & $\begin{array}{c}-0.0000^{* * *} \\
(0.0000)\end{array}$ \\
\hline $\mathrm{N}$ Consultation $=2$ & $\begin{array}{l}-0.0080 \\
(0.0098)\end{array}$ & $\begin{array}{l}-0.0007 \\
(0.0080)\end{array}$ & $\begin{array}{l}-0.0075 \\
(0.0098)\end{array}$ & $\begin{array}{c}0.0021 \\
(0.0079)\end{array}$ \\
\hline N Consultation $=3$ & $\begin{array}{c}-0.0525^{*} \\
(0.0275)\end{array}$ & $\begin{array}{c}-0.0977^{* * * *} \\
(0.0228)\end{array}$ & $\begin{array}{c}-0.0518^{*} \\
(0.0277)\end{array}$ & $\begin{array}{c}-0.0939^{* * *} \\
(0.0238)\end{array}$ \\
\hline Guaranteed Months $=60$ & $\begin{array}{c}0.0218 \\
(0.0380)\end{array}$ & $\begin{array}{c}0.1425^{* * *} \\
(0.0449)\end{array}$ & $\begin{array}{c}0.0224 \\
(0.0384)\end{array}$ & $\begin{array}{c}0.1438^{* * *} \\
(0.0452)\end{array}$ \\
\hline Guaranteed Months $=120$ & $\begin{array}{c}0.1009^{* * *} \\
(0.0110)\end{array}$ & $\begin{array}{c}0.1073^{* * *} \\
(0.0124)\end{array}$ & $\begin{array}{c}0.1005^{* * *} \\
(0.0109)\end{array}$ & $\begin{array}{c}0.1069^{* * *} \\
(0.0123)\end{array}$ \\
\hline Guaranteed Months $=180$ & $\begin{array}{c}0.1983^{* * *} \\
(0.0148)\end{array}$ & $\begin{array}{c}0.2422^{* * *} \\
(0.0152)\end{array}$ & $\begin{array}{c}0.1979^{* * *} \\
(0.0148)\end{array}$ & $\begin{array}{c}0.2411^{* * *} \\
(0.0149)\end{array}$ \\
\hline Guaranteed Months $=240$ & $\begin{array}{c}0.3332^{* * * *} \\
(0.0174)\end{array}$ & $\begin{array}{c}0.3965^{* * *} \\
(0.0124)\end{array}$ & $\begin{array}{c}0.3327^{* * *} \\
(0.0175)\end{array}$ & $\begin{array}{c}0.3949^{* * * *} \\
(0.0124)\end{array}$ \\
\hline Guaranteed Months $=360$ & $\begin{array}{c}0.5440^{* * *} \\
(0.0635)\end{array}$ & $\begin{array}{c}0.5932^{* * *} \\
(0.0387)\end{array}$ & $\begin{array}{c}0.5434^{* * *} \\
(0.0637)\end{array}$ & $\begin{array}{c}0.5885^{* * * *} \\
(0.0398)\end{array}$ \\
\hline Observations & 62,574 & 42,303 & 62,574 & 42,303 \\
\hline R-squared & 0.5252 & 0.4830 & 0.5252 & 0.4832 \\
\hline Year FE & YES & YES & YES & YES \\
\hline Firm FE & YES & YES & YES & YES \\
\hline Region FE & YES & YES & YES & YES \\
\hline
\end{tabular}

Note. Dependent variables: Initial prices. Sample: Only accepted offers. Standardized coefficients. Financial advisor, no beneficiary, early retirees, guaranteed months $=0$ and consultation $=1$ are the omitted categories. Robust standard errors clustered at the firm level in parentheses. ${ }^{* * *} \mathrm{p}<0.01,{ }^{* *} \mathrm{p}<0.05$, $* \mathrm{p}<0.1$ 
Table 8: Initial Prices, All offers

\begin{tabular}{|c|c|c|c|c|}
\hline & $\begin{array}{c}(1) \\
\text { Males }\end{array}$ & $\begin{array}{c}(2) \\
\text { Females }\end{array}$ & $\begin{array}{c}(3) \\
\text { Males }\end{array}$ & $\begin{array}{c}(4) \\
\text { Females }\end{array}$ \\
\hline Agent: Agent's Firm & $\begin{array}{c}0.0072 \\
(0.0070)\end{array}$ & $\begin{array}{c}0.0344^{* * *} \\
(0.0114)\end{array}$ & $\begin{array}{c}0.0092^{* * *} \\
(0.0003)\end{array}$ & $\begin{array}{c}0.0204^{* * * *} \\
(0.0008)\end{array}$ \\
\hline Agent: Other Firms & $\begin{array}{l}-0.0026^{*} \\
(0.0015)\end{array}$ & $\begin{array}{c}0.0056^{* * *} \\
(0.0016)\end{array}$ & & \\
\hline No Intermediary & $\begin{array}{c}0.0006 \\
(0.0045)\end{array}$ & $\begin{array}{c}0.0159^{* * *} \\
(0.0019)\end{array}$ & & \\
\hline Married & $\begin{array}{c}-0.1756^{* * * *} \\
(0.0060)\end{array}$ & $\begin{array}{c}-0.2267^{* * * *} \\
(0.0048)\end{array}$ & & \\
\hline Old Age Retirees & $\begin{array}{c}1.4412^{* * *} \\
(0.0542)\end{array}$ & $\begin{array}{c}2.2875^{* * *} \\
(0.1075)\end{array}$ & & \\
\hline Beneficiaries $=1$ & $\begin{array}{c}0.3989^{* * *} \\
(0.0066)\end{array}$ & $\begin{array}{c}0.3342^{* * *} \\
(0.0073)\end{array}$ & & \\
\hline Age & $\begin{array}{c}-0.6796^{* * * *} \\
(0.0223)\end{array}$ & $\begin{array}{c}-0.2827^{* * *} \\
(0.0491)\end{array}$ & & \\
\hline Age2 & $\begin{array}{c}0.0055^{* * *} \\
(0.0002)\end{array}$ & $\begin{array}{c}0.0026^{* * *} \\
(0.0004)\end{array}$ & & \\
\hline Savings & $\begin{array}{c}0.0043^{* * *} \\
(0.0003)\end{array}$ & $\begin{array}{c}0.0026^{* * *} \\
(0.0004)\end{array}$ & & \\
\hline Savings2 & $\begin{array}{c}-0.0000^{* * *} \\
(0.0000)\end{array}$ & $\begin{array}{c}-0.0000^{* * *} \\
(0.0000)\end{array}$ & & \\
\hline $\mathrm{N}$ Consultation $=2$ & $\begin{array}{c}-0.0133^{* * * *} \\
(0.0026)\end{array}$ & $\begin{array}{c}-0.0083^{* * *} \\
(0.0011)\end{array}$ & $\begin{array}{c}-0.0038^{* * *} \\
(0.0004)\end{array}$ & $\begin{array}{c}-0.0026^{* * *} \\
(0.0010)\end{array}$ \\
\hline $\mathrm{N}$ Consultation $=3$ & $\begin{array}{c}-0.0406^{* * *} \\
(0.0042)\end{array}$ & $\begin{array}{c}-0.0284^{* * *} \\
(0.0036)\end{array}$ & $\begin{array}{c}-0.0046^{* * *} \\
(0.0008)\end{array}$ & $\begin{array}{c}-0.0028 \\
(0.0019)\end{array}$ \\
\hline Guaranteed Months $=60$ & $\begin{array}{l}0.0106^{*} \\
(0.0053)\end{array}$ & $\begin{array}{c}0.0259 * * * \\
(0.0047)\end{array}$ & $\begin{array}{c}0.0094^{* * *} \\
(0.0010)\end{array}$ & $\begin{array}{c}0.0094^{* * *} * \\
(0.0018)\end{array}$ \\
\hline Guaranteed Months $=120$ & $\begin{array}{c}0.0800^{* * *} \\
(0.0020)\end{array}$ & $\begin{array}{c}0.0883^{* * *} \\
(0.0029)\end{array}$ & $\begin{array}{c}0.0795^{* * *} \\
(0.0002)\end{array}$ & $\begin{array}{c}0.0823^{* * *} \\
(0.0003)\end{array}$ \\
\hline Guaranteed Months $=180$ & $\begin{array}{c}0.1854^{* * *} \\
(0.0035)\end{array}$ & $\begin{array}{c}0.2065^{* * *} \\
(0.0049)\end{array}$ & $\begin{array}{c}0.1905^{* * *} \\
(0.0005)\end{array}$ & $\begin{array}{c}0.1999^{* * *} * \\
(0.0006)\end{array}$ \\
\hline Guaranteed Months $=240$ & $\begin{array}{c}0.3330^{* * *} \\
(0.0053)\end{array}$ & $\begin{array}{c}0.3854^{* * *} \\
(0.0068)\end{array}$ & $\begin{array}{c}0.3466^{* * *} \\
(0.0007)\end{array}$ & $\begin{array}{c}0.3771^{* * *} \\
(0.0011)\end{array}$ \\
\hline Guaranteed Months $=360$ & $\begin{array}{c}0.4730^{* * *} \\
(0.0124)\end{array}$ & $\begin{array}{c}0.5913^{* * *} \\
(0.0154)\end{array}$ & $\begin{array}{c}0.4966^{* * *} \\
(0.0026)\end{array}$ & $\begin{array}{c}0.5713^{* * *} \\
(0.0051)\end{array}$ \\
\hline Observations & $9,662,036$ & $6,477,366$ & $3,494,986$ & $2,207,777$ \\
\hline R-squared & 0.5106 & 0.4781 & 0.6446 & 0.5302 \\
\hline Year FE & YES & YES & YES & YES \\
\hline Firm FE & YES & YES & YES & YES \\
\hline Region FE & YES & YES & YES & YES \\
\hline Individual $\mathrm{FE}$ & NO & NO & YES & YES \\
\hline
\end{tabular}

Note. Dependent variables: Initial prices offered through SCOMP. Standardized coefficients. Financial advisor, no beneficiary, early retirees, guaranteed months $=0$ and consultation $=1$ are the omitted categories. Robust standard errors in parentheses clustered at the firm level in parenthesis. $* * * \mathrm{p}<0.01$, ** $\mathrm{p}<0.05, * \mathrm{p}<0.1$ 
Table 9: Initial Prices, Sample: Individuals accessing the market through a sales agent

\begin{tabular}{|c|c|c|}
\hline & $\begin{array}{c}(1) \\
\text { Males }\end{array}$ & $\begin{array}{c}(2) \\
\text { Females }\end{array}$ \\
\hline Agent's Firm & $\begin{array}{c}0.0104 \\
(0.0081)\end{array}$ & $\begin{array}{c}0.0294^{* *} \\
(0.0122)\end{array}$ \\
\hline Accepted & $\begin{array}{l}-0.0071 \\
(0.0201)\end{array}$ & $\begin{array}{c}-0.1034^{* *} \\
(0.0391)\end{array}$ \\
\hline Accepted*Agent's Firm & $\begin{array}{c}0.0112 \\
(0.0169)\end{array}$ & $\begin{array}{c}0.0655 \\
(0.0425)\end{array}$ \\
\hline Married & $\begin{array}{c}-0.1599 * * * \\
(0.0064)\end{array}$ & $\begin{array}{c}-0.2232^{* * *} \\
(0.0047)\end{array}$ \\
\hline Old Age Retirees & $\begin{array}{c}1.4084^{* * *} \\
(0.0474)\end{array}$ & $\begin{array}{c}2.1311^{* * *} \\
(0.0987)\end{array}$ \\
\hline Beneficiaries & $\begin{array}{c}0.4009^{* * *} \\
(0.0089)\end{array}$ & $\begin{array}{c}0.3266^{* * *} \\
(0.0104)\end{array}$ \\
\hline Age & $\begin{array}{c}-0.7209^{* * *} \\
(0.0225)\end{array}$ & $\begin{array}{c}-0.1828^{* * *} \\
(0.0437)\end{array}$ \\
\hline Age2 & $\begin{array}{c}0.0058^{* * *} \\
(0.0002)\end{array}$ & $\begin{array}{c}0.0018^{* * *} \\
(0.0003)\end{array}$ \\
\hline Pen Savings & $\begin{array}{c}0.0052^{* * *} \\
(0.0004)\end{array}$ & $\begin{array}{c}0.0029^{* * *} \\
(0.0005)\end{array}$ \\
\hline Pen Savings 2 & $\begin{array}{c}-0.0000^{* * *} \\
(0.0000)\end{array}$ & $\begin{array}{c}-0.0000^{* * *} \\
(0.0000)\end{array}$ \\
\hline $\mathrm{N}$ Consultation $=2$ & $\begin{array}{c}-0.0090^{* * *} \\
(0.0017)\end{array}$ & $\begin{array}{c}-0.0172^{* * *} \\
(0.0019)\end{array}$ \\
\hline $\mathrm{N}$ Consultation $=3$ & $\begin{array}{c}-0.0409^{* * *} \\
(0.0023)\end{array}$ & $\begin{array}{c}-0.0210^{* * *} \\
(0.0044)\end{array}$ \\
\hline Guaranteed Months $=60$ & $\begin{array}{c}0.0273^{* * *} \\
(0.0080)\end{array}$ & $\begin{array}{c}0.0583^{* * *} \\
(0.0065)\end{array}$ \\
\hline Guaranteed Months $=120$ & $\begin{array}{c}0.0823^{* * *} \\
(0.0020)\end{array}$ & $\begin{array}{c}0.0857^{* * *} * \\
(0.0028)\end{array}$ \\
\hline Guaranteed Months $=180$ & $\begin{array}{c}0.1844^{* * *} \\
(0.0034)\end{array}$ & $\begin{array}{c}0.1996^{* * * *} \\
(0.0046)\end{array}$ \\
\hline Guaranteed Months $=240$ & $\begin{array}{c}0.3283^{* * *} \\
(0.0053)\end{array}$ & $\begin{array}{c}0.3721^{* * * *} \\
(0.0063)\end{array}$ \\
\hline Guaranteed Months $=360$ & $\begin{array}{c}0.4466^{* * *} \\
(0.0120)\end{array}$ & $\begin{array}{c}0.5494^{* * *} \\
(0.0107)\end{array}$ \\
\hline Observations & $3,494,986$ & $2,207,777$ \\
\hline R-squared & 0.5094 & 0.4656 \\
\hline Year FE & YES & YES \\
\hline Firm FE & YES & YES \\
\hline Region FE & YES & YES \\
\hline
\end{tabular}

Note. Dependent variables: Initial prices offered through SCOMP. Standardized coefficients. Sample: Individuals accessing the market through a sales agent. Financial advisor, no beneficiary, early retirees, guaranteed monthg $=0$ and consultation $=1$ are the omitted categories. Robust standard errors clustered at the firm level in parenthesis. $* * * \mathrm{p}<0.01$, $* * \mathrm{p}<0.05, * \mathrm{p}<0.1$ 
Appendix

Figure A.1: The SCOMP System

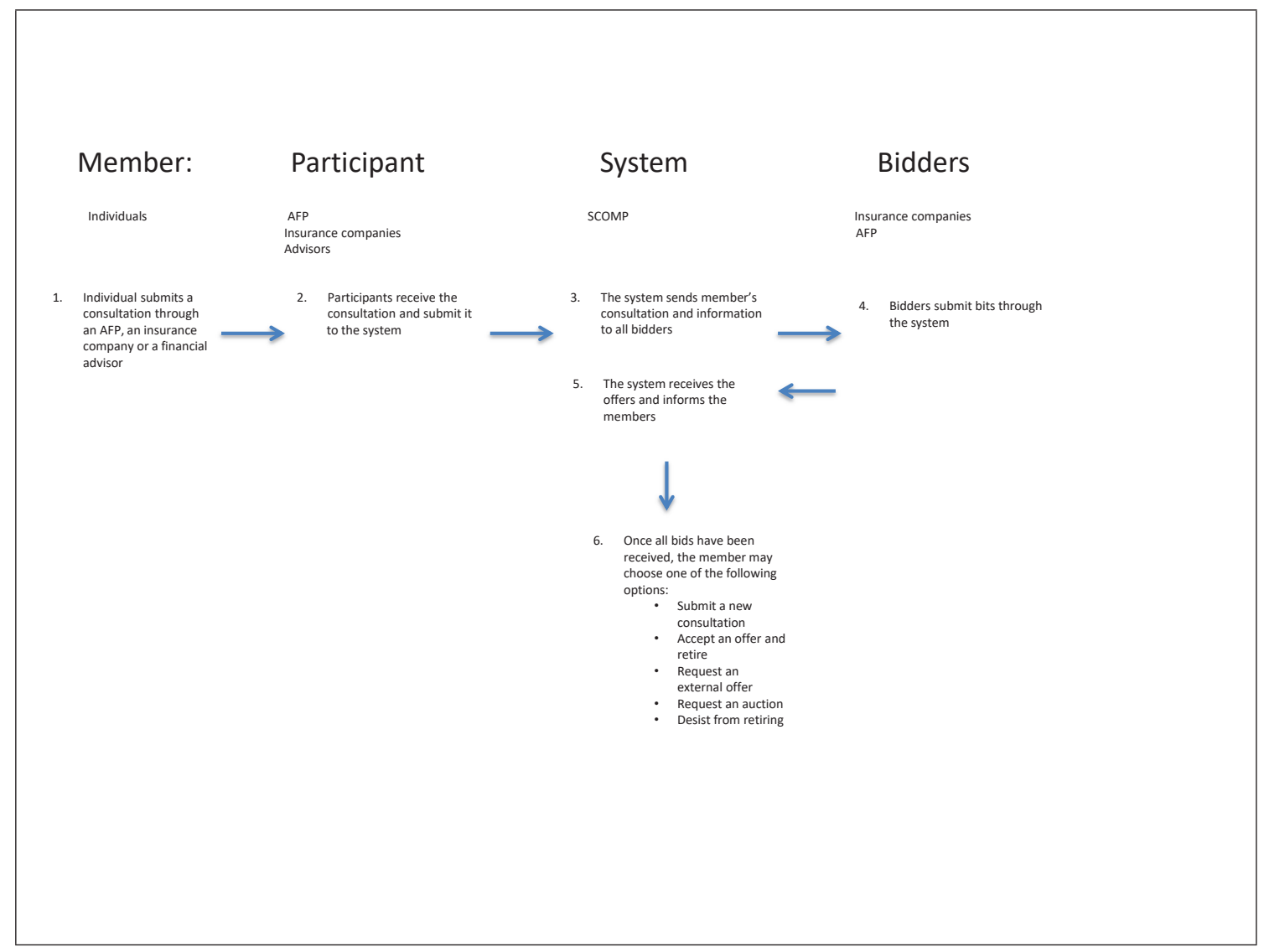


Figure A.2: Share of individuals by channel used for market access

(a) Men

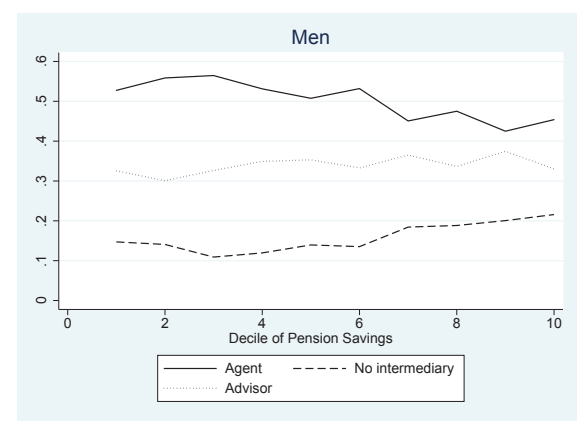

(b) Women

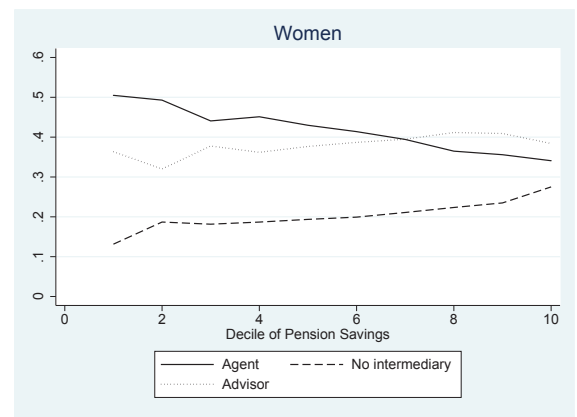

Note. The figure shows the share of individuals in each decile of pension wealth by access channel used.

Figure A.3: Number of internal offers per individual and pension product

(a) Decile of Pension Savings

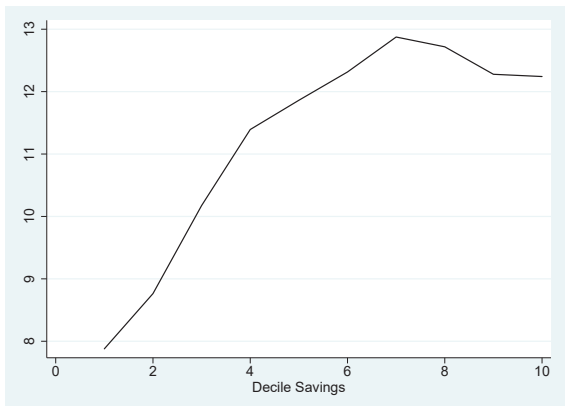

(b) Age and Gender

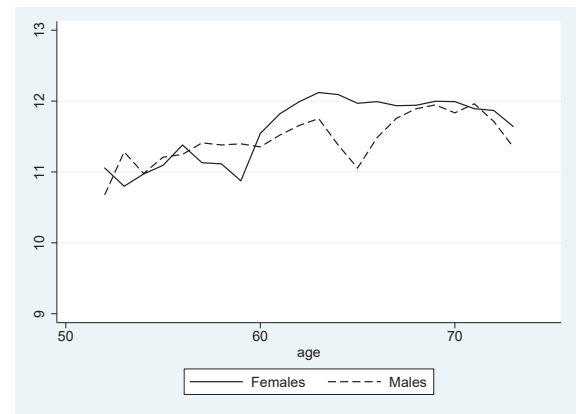

Note. The figure shows the average number of offers received by an individual, by decile of pension wealth or gender and age. 
Figure A.4: Average differences in the benefit payment across offers

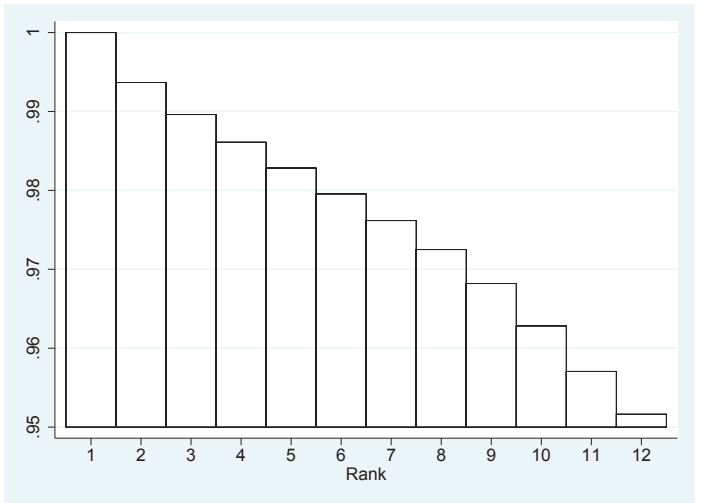

Note. The figure shows the percentage difference in the benefit payment between the highest offer and any other offer received by an individual, based on ranking of the initial offer. Offers are ranked according to their monthly benefit payment. The offer with the lowest rank (1) corresponds to the offer with the highest benefit payment.

Figure A.5: Characteristics of the firms making the accepted offers: Risk-rating class

(a) Men

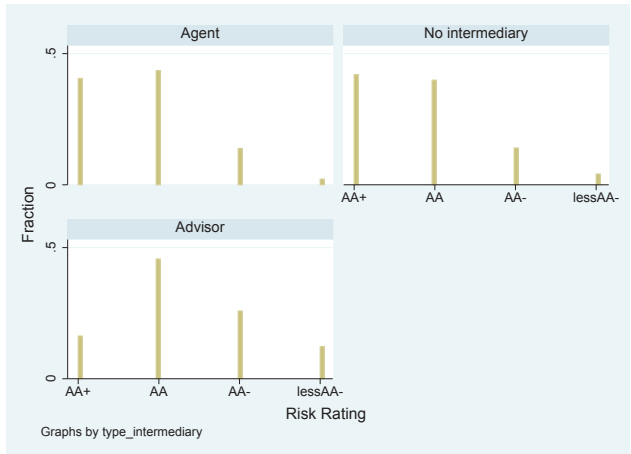

(b) Women

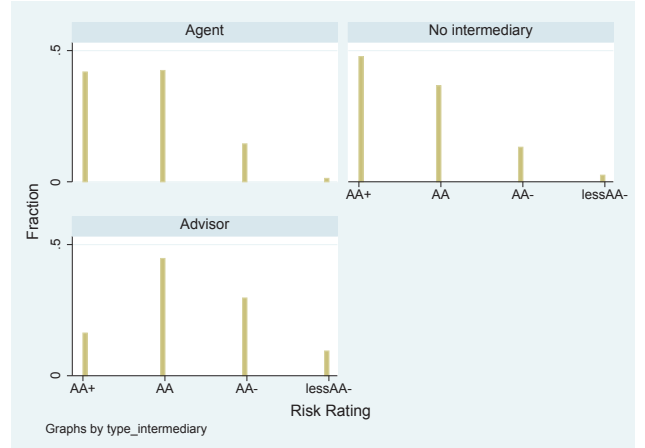

Note. The table shows the share of individuals by the risk-rating class of the firm making the accepted offer. 


\section{IdEP Economic Papers}

The series IdEP Economic Papers, ideally continues the work of the "Quaderni della Facoltà" the publication of which began in 1998 and ended in 2013.

For a complete list of the Quaderni see: http://econpapers.repec.org/paper/lugwpaper/

IdEP Economic Papers also gathers the legacy of the CEPRA Working Papers, published from 2012 to 2013.

The full list at: http://econpapers.repec.org/paper/lugwcepra/

2014:

No. 01

F. Mazzonna, F. Peracchi, Unhealthy retirement? Evidence of occupation heterogeneity

No. 02

L. Di Giorgio, M. Filippini, G. Masiero, The relationship between costs and quality in nonprofit nursing homes

No. 03

F.C. Billari, V. Galasso, Fertility decisions and pension reforms : evidence from natural experiments in Italy

No. 04

M. Jametti, M. Joanis, Elections and de facto expenditure decentralization in Canada

No. 05

M. Jametti, Weathering the global financial crisis : is direct democracy of any help?

No. 06

U. Pagano, M. Vatiero, Costly institutions as substitutes : novelty and limits of the Coasian approach

No. 07

R. Parchet, Are local tax rates strategic complements or strategic substitutes?

No. 08

R. Ippoliti, M. Vatiero, An analysis of how 2002 judicial reorganization has impacted on the performance of the First Instance Courts (Preture) in Ticino

No. 09

F. Mazzonna, P. Salari, Short term effects of public smoking bans on health 
2015:

No. 01

S. Galletta, Direct democracy, partial decentralization and voter information : evidence from Swiss municipalities

No. 02

I. Sarman, Second homeowners' intention to move : an integrated ordered logit model with latent variable

No. 03

M.J. Roe, M. Vatiero, Corporate governance and its political economy

No. 04

M. Filippini, M. Koller, G. Masiero, Competitive tendering versus performance-based negotiation in Swiss public transport

No. 05

O. Giuntella, F. Mazzonna, If you don't snooze you lose health and gain weight : evidence from a regression discontinuity design

No. 06

M. Filippini, B. Hirl, G. Masiero, Rational habits in residential electricity demand

2016:

No. 01

S. Galletta, Law enforcement, municipal budgets and spillover effects : evidence from a quasiexperiment in Italy

No. 02

S. Galletta, A. Redonda, Corporate flat tax reforms and businesses'location choices. Evidence from Switzerland

No. 03

M. Filippini, W. Greene, G. Masiero, Persistent and transient productive inefficiency in a regulated industry : electricity distribution in New Zealand 
No. 04

M. Vatiero, On the (political) origin of "corporate governance" species

No. 05

E. Gentili, G. Masiero, F. Mazzonna, The role of culture in long-term care

No. 06

M. Vatiero, Learning from the Swiss corporate governance exception

No. 07

F. Cavalcanti, G. Daniele, S. Galletta, Popularity shocks and political selection : the effects of anti-corruption audits on candidates' quality

2017:

No. 01

P. Bello, Exchange rate fluctuations and border crossings : evidence from the Swiss-Italian border

No. 02

E. Gentili, F. Mazzonna, What drives the substitutability between native and foreign workers? Evidence about the role of language

No. 03

G. Daniele, S. Galletta, B. Geys, Abandon ship? Party brands and politicians' responses to a political scandal

2018:

No. 01

G. Masiero, F. Mazzonna, O. Verbeek, What drives the rise of antidepressant consumption? Evidence from Switzerland

No. 02

U. Pagano, M. Vatiero, Positional goods and legal orderings 
2019:

No. 01

G. Masiero, M. Santarossa, Earthquakes, grants and public expenditure : how municipalities respond to natural disasters

No. 02

G. Masiero, F. Mazzonna, S. Steinbach, O. Verbeek, The effect of local growth in antidepressant consumption on mental health outcomes

No. 03

T. Ly, Taxes, traffic jam and spillover in the metropolis

2020:

No. 01

P. Bello, The environmental cost and the accident externality of driving: evidence from the Swiss franc's appreciation

No. 02

P. Bello, Gender-based price discrimination in the annuity market: evidence from Chile 